\section{EXCLUSIÓN Y DESIGUALDAD ESPACIAL: Retrato desde la movilidad cotidiana ${ }^{1}$}

Paola Jirón M. ${ }^{2}$

Carlos Lange V. ${ }^{3}$

María Bertrand S. ${ }^{4}$

\section{EXCLUSION AND SPATIAL INEQUALITY: An analysis from a daily mobility perspective ${ }^{1}$}

Paola Jirón M. ${ }^{2}$

Carlos Lange V. ${ }^{3}$

María Bertrand S. ${ }^{4}$

\section{Resumen}

La movilidad cotidiana urbana es uno de los fenómenos más complejos y relevantes de las configuraciones y organizaciones espaciales contemporáneas. Sin embargo -desconociendo los aportes de las teorías de urbanismo- su espacialidad ha sido desarticulada por planificaciones que desconocen la dimensión antropológica de los espacios de los grupos humanos. El presente artículo tiene por objetivo desarrollar y fundamentar una problematización de la exclusión social urbana desde la perspectiva de la movilidad cotidiana urbana. Lo anterior adquiere relevancia en la medida que permite poner sobre el tapete los alcances teóricoconceptuales desarrollados recientemente sobre ambos conceptos, permite analizar los vínculos y relaciones existentes entre ambos y su importancia

\section{Abstract}

Daily urban mobility is one of the most complex and relevant phenomena of contemporary spatial configurations and organizations. However, ignoring contributions from theories of urbanism, its spatiality has been disarticulated by planners who are unawate of the anthropological dimensions of spaces of human beings. The following article tries to develop and problematise urban social exclusion from an urban daily mobility point of view. This approach is important as it sets out the theoretical-conceptual contributions developed recently on both concepts; it analyses the links and relationships between 
para la comprensión del espacio urbano, y por último, permite poner en el centro de la discusión a los sujetos urbanos como principales protagonistas de los conceptos en discusión.

\section{PALABRAS CLAVES: MOVILIDAD COTIDIANA, EXCLUSIÓN SOCIAL, EXPERIENCIA, ESPACIALIDAD, SANTIAGO DE CHILE.}

Fecha de Recepción: 23.11.2009

Fecha de Aceptación: 29.03.2010

1 Este trabajo se basa en el Proyecto de Investigación FONDECYT $N^{\circ} 1090198$ "Movilidad Cotidiana Urbana Y Exclusión Social Urbana En Santiago De Chile"

2 Chilena, BComm, MSc, PhD Planificación Urbana, Académica INVI, Facultad de Arquitectura y Urbanismo, Universidad de Chile. Correo Electrónico: pjiron@uchile.cl

3 Chileno, Lic. en Antropologia, MSc, Académico INVI, Facultad de Arquitectura y Urbanismo, Universidad de Chile.

Correo Electrónico: clange@uchile.cl

4 Chilena, Urbanista, PhD. Académica Departamento de Urbanismo, Facultad de Arquitectura y Urbanismo, Universidad de Chile. Correo Electrónico: mbretrand@uchile.cl

16 revista invi № 68 / Mayo 2010 / Volume № 25: 15-57 both concepts and their importance to the understanding of urban space; and it sets urban subjects as key figures in the concepts in discussion.

\section{KEYWORDS: DAILY MOBILITY, SOCIAL EXCLUSION, EXPERIENCE, SPATIALITY, SANTIAGO DE CHILE.}

Received: 23.11.2009

Accepted: 29.03.2010

1 This work is based on the FONDECYT Research Project No 1090198 "Urban Daily Mobility and Urban Social Exclusion in Santiago de Chile"

2 Chilean, BComm, MSc, PhD Urban Planning, INVI Academic, Facultad de Arquitectura y Urbanismo, Universidad de Chile. Email: pjiron@uchile.cl

3 Chilean, Bachelor in Anthropology, MSc, INVI Academic, Facultad de Arquitectura y Urbanismo, Universidad de Chile. Email: clange@uchile.cl

4 Chilean, Urbanist, PhD. Departament of Urbanism Academic, Facultad de Arquitectura y Urbanismo, Universidad de Chile. Email:mbertrand@uchile.cl

ARTICLE: Exclusion and spatial inequality: An analysis from a daily mobility perspective / Paola Jirón M., Carlos Lange V., María Bertrand S. 


\section{Introducción}

A fines de la pasada década, y en referencia al preponderante rol asumido por Santiago de Chile como centro urbano articulador de la incorporación del país al proceso de globalización, de Mattos destacaba tres importantes transformaciones experimentadas por la morfología santiaguina durante los últimos treinta años: tendencia hacia la suburbanización con la formación de un periurbano difuso, conformación de una estructura metropolitana polarizada y segregada, e irrupción de un conjunto de nuevos artefactos urbanos, con gran capacidad para reestructurar el espacio metropolitano ${ }^{5}$. Transcurrida una década de tal diagnóstico, las características identificadas y descritas en él parecen haberse acentuado y consolidado progresivamente.

Por una parte, y de acuerdo a lo reseñado por Galetovic y Jordán ${ }^{6}$, la expansión de la superficie urbana de Santiago pasó de 49.270 há en 1992, considerando las 32 comunas de la Provincia de Santiago más Puente Alto y San Bernardo, a 64.140 há en 2002, considerando las 37 comunas reguladas por el PRMS ${ }^{7}$ de 1994. Dicho crecimiento aparece asociado a un conjunto de factores importantes como son, por ejemplo, la ocupación expansiva que se

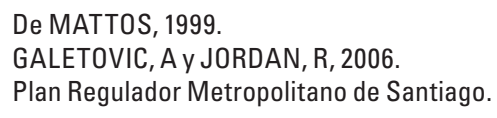

ARTÍCULO: Exclusión y desigualdad espacial: Retrato desde la movilidad cotidiana / Paola Jirón M., Carlos Lange V., María Bertrand S.

\section{Introduction}

At the end of the last decade, and referring to the predominant role assumed by Santiago de Chile as the urban center that led the country into the globalization process, de Mattos ${ }^{5}$ pointed out three important transformations experienced by Santiago morphology during the last thirty years: a suburbanization trend produced by the formation of a diffuse periurban area; a formation of a polarized, segregated metropolitan structure; and a sudden emergence of a group of new urban artifacts capable of reorganizing the metropolitan space. A decade after that diagnosis, the identified features seem to have progressively increased and consolidated.

Firstly, and according to Galetovic and Jordán ${ }^{6}$, the expansion of the urban surface of Santiago changed from 49,270ha in 1992 -taking into account the 32 municipalities of the Santiago Province plus Puente Alto and San Bernardoto 64,140 ha in 2002 -taking into account the 37 municipalities regulated by the Metropolitan

\footnotetext{
De MATTOS, 1999.

GALETOVIC, A \& JORDAN, R. 2006.
} 
ha hecho de las áreas rurales periféricas de Santiago, el desarrollo de asentamientos inmobiliarios de tipo urbano y semiurbano, y la incorporación de centros urbanos aledaños a Santiago como San Bernardo, Puente Alto, Maipú, Colina, entre otros. Este proceso ha implicado una redistribución tanto de su población como de las distintas actividades -residenciales, culturales y de recreación, comerciales, industriales, de servicios, etc- existentes en su interior.

Por otra parte, la irrupción de nuevos artefactos metropolitanos puede observarse a partir de la interrelación de tres componentes: las masivas obras de infraestructura para la movilidad, como son la red de metro, carreteras suburbanas concesionadas, vías exclusivas para transporte público, entre otras que proliferan en la ciudad; la preeminencia que mejores y más modernos medios de transporte motorizados han alcanzado como respuesta a los requisitos de conectividad durante los últimos años ${ }^{8}$; los importantes esfuerzos por diseñar, implementar y operar un servicio de transporte público que permita mejorar la conectividad y accesibilidad al interior de la ciudad, y facilitar la

8 De acuerdo con la Encuesta Origen Destino (SECTRA 2002), el sostenido aumento experimentado por los viajes motorizados realizados en Santiago en día laboral -,pasando desde un total de 5.996.118 viajes en 1991 a 10.147.247 viajes en 2001-, y el incremento observado en el parque automotriz de la capital durante los últimos 20 años -que puede observarse en el incremento de la tasa de autos por hogar entre $1977(0,32), 1991(0,36)$ y 2001 $(0,56)-$, dan cuenta de este fenómeno.

18 revista invi № 68 / Mayo 2010 / Volume № 25: 15-57
Master Plan of Santiago-. That growth is associated with a series of important factors such as the extensive occupation of rural areas in the outskirts of Santiago, the development of urban and semiurban residential projects and the incorporation of urban centers next to Santiago such as San Benardo, Puente Alto, Maipú and Colina. This process has entailed the redistribution of both its population and activities (residential, cultural, recreational, commercial, industrial, service sector, etc.)

Secondly, the emergence of new metropolitan artifacts can be understood by the interrelationship of three factors: the massive pieces of infrastructure designed for mobility such as the underground network, the concessioned suburban motorways, and the exclusive lanes for public transport, to name some a few; better and more modern motorized means of transport as a response to connectivity demands during

$7 \quad$ PRMS in Spanish. 
conexión con zonas urbanizadas adyacentes, como ha sido el caso de Transantiago.

Por último, los dos factores anteriormente descritos aparecen asociados a la existencia de una estructura metropolitana polarizada y segregada, con una marcada diferenciación entre grupos socioeconómicos. Mientras las clases altas han intensificado su desplazamiento hacia sectores considerados exclusivos y privilegiados (Providencia, Las Condes, Vitacura, Lo Barnechea por el Oriente; Huechuraba, Quilicura, Lampa por el Norte; Peñalolén, La Florida y Pirque por el Sur; Paine y Buin por el Poniente), las clases medias han mantenido su ocupación preponderante de comunas tradicionales (Ñuñoa, La Reina, La Florida, San Miguel, Maipú), y las clases bajas han debido iniciar también un traslado hacia los sectores más subvalorados y desprovistos de la capital como Puente Alto, La Pintana, San Bernardo, el mismo Maipú, Cerrillos y comunas del sector Norte, debido a su dependencia frente a soluciones habitacionales baratas ubicadas en dichos sectores ${ }^{9}$.

Pese a la concreción del diagnóstico morfológico realizado hace ya diez años, en el análisis y discu-

9 DUCCI, 2000. the last years 8 ; and the efforts for designing, implementing and putting into practice a public service transport capable of improving the connectivity and accessibility within the city in order to facilitate the connection with other urban areas, as in the case of Transantiago.

Lastly, the two aforementioned factors are associated with a polarized and segregated metropolitan structure, with a clear difference among socio-economic groups. While the migration of higher class groups towards areas regarded as exclusive and privileged (Providencia, Las Condes, Vitacura and Lo Barnechea on the east; Huechuraba, Quilicura and Lampa on the north; Peñalolén, La Florida and Pirque on the south; Paine and Buin on the west) is increasing, the middle class groups are still living in their traditional districts (Ñuño, La Reina, La Florida, San Miguel and Maipu), and the lower class groups, due to their dependence on subsidized housing ${ }^{9}$, have moved

\footnotetext{
8 According to Origin Destination Survey (SECTRA 2002) examples of this phenomenon include: the increase of motorized trips in Santiago on workdays -from 5,996,118 in 1991 to $10,147,247$ in 2001- and the growth of the automotive fleet in the capital during the last 20 years -increase of automobiles per household between 1977 (0.32), 1991 (0.36) and 2001 (0.56)
} 
sión respecto a las causas, implicancias y consecuencias de estos fenómenos aparece ausente uno de los elementos más relevantes en la discusión urbana actual: la movilidad cotidiana urbana.

En este sentido, la creciente distancia que separa tanto a los proyectos inmobiliarios privados como a los conjuntos de vivienda social ubicados en las periferias de la ciudad de las zonas centrales donde se concentra el empleo, la recreación, los servicios, entre otras actividades, convierte a la movilidad cotidiana urbana en un factor relevante de análisis y discusión para la comprensión que las transformaciones anteriormente referidas generan para la calidad de vida de la población. Por ejemplo, el Censo realizado en nuestro país el año 2002 preguntó por primera vez respecto a destinos de movilidad cotidiana de las personas en relación al trabajo o estudio. Los resultados fueron ilustrativos respecto de la relación entre movilidad cotidiana urbana y desigualdad, considerando que aquellos con menores niveles de educación e ingreso presentaron una movilidad bastante menor que aquellos con niveles de educación e ingreso más alto ${ }^{10}$. Esto se condice con las posibilidades de transporte presente para cada uno de estos grupos. Mientras los grupos de menores ingresos se transportan peatonalmente, en bicicletas y transporte públi$\mathrm{co}$, los grupos de mayores ingresos concentran

10 DELAUNAY, 2007.

20 revista invi № 68 / Mayo 2010 / Volume № 25: 15-57 towards the most devaluated and marginalized areas of the city (Puente Alto, La Pintana, San Bernardo, some zones of Maipú, Cerrillos and districts in the eastern part of Santiago.)

Although the projections of the diagnosis made ten years ago were correct, the analysis and discussion of the causes and consequences of these phenomena do not mention one of the most important elements of current urban debate: urban daily mobility.

In this sense, the increasing distance that separates both private as well as social housing projects located on the outskirts of the city from the central zones which concentrate employment, recreation and services sectors, turns urban daily mobility into a significant element of analysis and discussion to understand the effects of the transformations previously mentioned on the population quality of life. For instance, the 2002 census asked for the first time about the destination of daily mobility of people in relation to their workplace or educational institutions. The results showed that people with less resources and lower education level have less mobility than people with more 
la propiedad de transporte privado. En 2001 los 970,000 automóviles existentes en Santiago se concentraban sólo en el 35\% de los hogares de más altos ingresos ${ }^{11}$.

El caso de Santiago de Chile, descrito sucintamente en los párrafos precedentes, posiblemente ilustre lo sucedido en las principales metrópolis latinoamericanas durante la última década. Ello confirma la importancia de abordar la movilidad cotidiana urbana tanto como objeto de estudio y como enfoque teórico-metodológico, principalmente por su directa relación con una accesibilidad desigual y su impacto en las formas de exclusión social existentes en los grandes centros urbanos.

De este modo, la movilidad cotidiana urbana constituye una práctica social cada vez más masiva, recurrente y compleja, fuertemente condicionada con los altos niveles de desigualdad existentes en la ciudad. Por esta razón, el estudio de las estrategias y experiencias de movilidad cotidiana urbana permiten sustentar un enfoque crítico para analizar las relaciones sociales urbanas y particularmente aquellas que conllevan procesos de exclusión social. Por una parte, permiten analizar críticamente la forma como se piensa, planifica y gestiona la ciudad. Por otra, permite incorporar las

11 SECTRA, 2002. resources and higher level of education ${ }^{10}$. This is consistent with the transport possibilities of each group. While lower income groups commute by walking, cycling or by public transport means, higher income groups concentrate the use of private transport. In 2001, the existent 970,000 automobiles in Santiago were concentrated on the $35 \%$ of higher income households ${ }^{11}$.

The situation experienced by Santiago de Chile may illustrate the changes taking place in the main Latin American metropolises during the last decade. This confirms the importance of addressing urban daily mobility as a research subject and as a theoretical-methodological approach, mainly for its relationship with an uneven accessibility and its impact on existing social exclusion in urban centers.

In this manner, urban daily mobility is increasingly becoming a massive, recurrent and complex social practice determined by existing inequality in the city. For this reason, the study of urban daily mobility strategies and experiences allow for a critical approach to analyze urban

10 DELAUNAY, 2007.

11 SECTRA, 2002. 
transformaciones en los modos de vida de los habitantes urbanos a partir de su cotidianidad, elemento fundamental pero que no ha sido suficientemente reconocido por las disciplinas encargadas de dicha labor.

En base a esto, el presente artículo tiene por objetivo desarrollar y fundamentar una problematización de la exclusión social urbana desde la perspectiva de la movilidad cotidiana urbana. Lo anterior adquiere relevancia en la medida que permite poner sobre el tapete los alcances teóricoconceptuales desarrollados recientemente sobre ambos conceptos, permite analizar los vínculos y relaciones existentes entre ambos y su importancia para la comprensión del espacio urbano, y por último, permite poner en el centro de la discusión a los sujetos urbanos como principales protagonistas de los conceptos en discusión.

\section{La importancia de la movilidad cotidiana desde las ciencias sociales y los estudios urbanos}

Durante la última década, distintos autores han hecho referencia a la importancia que el 'giro de movilidad' ha tenido para la investigación urbana en las ciencias sociales y para una re-conceptualización de los temas y materias de decisión del

22 revista invi № 68 / Mayo 2010 / Volume № 25: 15-57 social relationships and, specifically, those that lead to social exclusion. It takes into account the transformations taking place in the lives of urban residents from an everyday life point of view, this being a key element that has not been properly studied.

Based on this, this paper aims at developing a problematization of urban social exclusion from an urban daily mobility point of view. This is particularly relevant as it sets out the theoretical-conceptual contributions developed recently on both concepts; it analyses the existing links and relationships between both concepts and their importance to the understanding of urban space; and it sets urban subjects as key figures in the concepts in discussion.

\section{The importance of daily mobility from a social sciences and urban studies perspective}

During the last decade, different authors have pointed out the importance of the mobility turn in social sciences in the field of urban research and for a significant for reorganization of key 
urbanismo ${ }^{12}$. Dicha perspectiva dice relación con los inevitables impactos que los distintos tipos de movilidad, incluyendo la migración, el turismo, la movilidad residencial o la movilidad cotidiana urbana, tienen en la organización social y espacial de la vida cotidiana contemporánea. La movilidad puede ser vista como un emblema de los tiempos actuales, y pese a que históricamente nuestras sociedades han sido caracterizadas por un progresivo aumento en la movilidad en los distintos ámbitos de la vida cotidiana ${ }^{13}$, sus múltiples formas, velocidad y variedad observadas en la actualidad no tienen precedente.

En este sentido, y pese a la importancia que tienen los viajes esporádicos a niveles internacionales o de largas distancias, los desplazamientos cotidianos siguen siendo altamente significativos en el análisis urbano y requieren de una cuidadosa consideración, precisamente porque es en la experiencia cotidiana que se pueden comprender varios aspectos de la calidad de vida urbana. Asimismo, las preocupaciones actuales no se refieren simplemente al viaje hacia y desde el trabajo, sino a los múltiples viajes que crecientemente son necesarios para mantener un estilo de vida y organizar las actividades cotidianas. Los temas de cómo llegar a algún lugar están inevitablemente vinculados a la

\footnotetext{
12 CRESSWELL, 2006; HANNAM, SHELLER Et AI. 2006; SHELLER Y URRY, 2006; URRY, 2007.
}

13 BOURDIN, 2003. elements in urbanism ${ }^{12}$. Such perspective is related to unavoidable impacts caused by different types of mobility, including migration, tourism, residential mobility or urban daily mobility, in social and spatial organization of current daily life. Mobility might be seen as a sign of modern times, and despite the fact that our societies have been historically determined by increasing mobility in different aspects of daily life ${ }^{13}$, its current multiple forms, speed and variety are unprecedented.

In this sense, even though the importance of sporadic international or long distance trips, daily movement is still significant for urban analysis. This requires close attention, as daily experience can be useful to understand different aspects of urban life quality. Likewise, current concerns are not only related to commuting to and from work, but also to the increasingly multiple trips needed to maintain a lifestyle and to organize daily activities. Topics about how to reach a specific destination are

\footnotetext{
12 CRESSWELL, 2006; HANNAM, SHELLER Et AI. 2006; SHELLER \& URRY, 2006; URRY, 2007.

13 BOURDIN, 2003.
} 
forma en que se vive y planifica en las ciudades de hoy $^{14}$.

Lo anterior permite comprender la importancia fundamental que la movilidad cotidiana posee en la organización de la vida urbana contemporánea. En este sentido se entenderá la movilidad cotidiana urbana como aquella práctica social de desplazamiento diario a través del tiempo y espacio urbano que permite el acceso a actividades, personas y lugares. Este enfoque involucra además entender las consecuencias sociales, económicas, culturales y espaciales que genera sobre la conformación del espacio urbano y los distintos tipos de experiencia de sus habitantes

Una primera característica distintiva de la movilidad lo constituye su carácter co-presencial, con su correlato de condiciones espaciales afines a los diferentes tipos de co-presencia. Si bien la movilidad cotidiana puede ser física, virtual o imaginaria ${ }^{15}$, y los avances tecnológicos como la televisión, Internet o telefonía móvil otorgan la posibilidad de estar presentes en más de un lugar a la vez, para la mayoría de las personas, la vida social aún se conforma a partir de reuniones intermitentes que se engendran mediante el viaje físico ${ }^{16}$. Tanto el encuentro como las diversas formas de desplazamiento que lo posibilitan son centrales para el de-

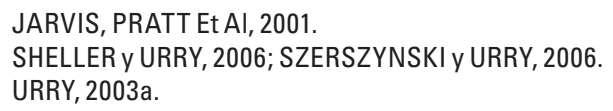

24 revista invi № 68 / Mayo 2010 / Volume № 25: 15-57 inevitably connected to lifestyles and planning in contemporary cities ${ }^{14}$.

In this way, daily mobility can be understood as crucial in current urban life organization. Urban daily mobility is therefore understood as a social practice of daily movement through urban space and time, granting access to activities, people and places. This approach also involves understanding the social, economic, cultural and spatial consequences of daily mobility on urban space structure and the different experiences of inhabitants.

Co-presence, and the spatial conditions that best suit the different types of co-presence, are the first distinctive characteristics of mobility. Although daily mobility might be physical, virtual or imaginary ${ }^{15}$; and technological advances such as the television, the Internet or mobile networks allow individuals to be in different places at the same time, for the majority of people, social life is still determined by sporadic encounters that take place during physical trips ${ }^{16}$. Both encounters and the different forms of movement
14 JARVIS, PRATT Et Al, 2001.
15 SHELLER \& URRY, 2006; SZERSZYNSKI \& URRY, 2006.

16 URRY, 2003 ${ }^{\mathrm{a}}$. 
sarrollo de la vida social, una vida que combina el aumento de distancias y de co-presencias intermitentes ${ }^{17}$. La comunicación y los viajes que se requieren para esta co-presencia son multifacéticos, contienen gran riqueza y parecieran transformar la naturaleza misma de la vida social ${ }^{18}$.

En segundo lugar, el concepto de espacio-temporal alude a la indisociable interconexión entre ambos elementos, intentando superar la dualidad de su comprensión como realidades separadas. La concepción del espacio-temporal como un proceso multidimensional, dispar y siempre parcial, se vuelve relevante en el contexto de la vida urbana contemporánea móvil ya que transforma la naturaleza y la experiencia de ambas nociones en la vida urbana $^{19}$.

Según Sheller y Urry ${ }^{20}$, este giro de la movilidad presenta implicancias teóricas, metodológicas y prácticas importantes para las ciencias sociales, que sólo ahora se empiezan a descubrir, y por ende implicarían un cambio en la manera cómo se abordan los estudios urbanos y los procesos del urbanismo. Desde la invención del tren y el automóvil, el desarrollo urbano y la forma urbana específicamente han sido desarrollados principalmente por el objetivo de aumentar y facilitar la circula-

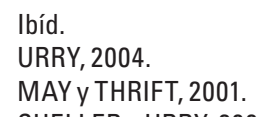

ARTÍCULO: Exclusión y desigualdad espacial: Retrato desde la movilidad cotidiana / Paola Jirón M., Carlos Lange V., María Bertrand S. are essential for the development of a social life that combines increasing distances and intermittent copresence ${ }^{17}$. Communication and trips required for co-presence can be are rich and varied and seem to transform the nature of social life $e^{18}$.

The space-time concept refers to the connection between both elements, transcending their independent definitions. The conception of space-time, as a multidimensional, uneven, and partial process, becomes important for mobile urban life, as it transforms the nature and experience of urban space and time $e^{19}$.

According to Sheller and Urry ${ }^{20}$, this mobility turn presentsnew theoretical and methodological implications and important practices for social sciences. Therefore, these new elements present a change in the way urban research and urban processes are addressed. Since the invention of the locomotive, urban development and specifically the urban form have been developed to increase and make easy the movement through

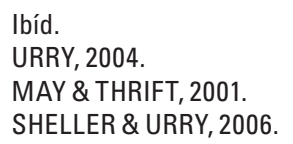

revista invi № 68 / May 2010 / Volume № 25: 15-57 
ción mediante la creación de caminos, avenidas y autopistas $^{21}$, lo que significa que la promoción del movimiento ha estado al centro de la planificación urbana. Esta tendencia se ve en progresivo aumento producto de los procesos de suburbanización experimentado por los grandes centros urbanos y producto de los requerimientos de conectividad física y virtual surgidos como parte de su incorporación a los circuitos de la globalización.

Sin embargo, el análisis de los fenómenos urbanos ha sido generalmente estático, buscando comprender cómo la vida de las personas se desarrolla en localidades fijas, ignorando o trivializando el movimiento de las personas al trabajo, familia, ocio y placer, y cómo ellas se adaptan o son adaptadas, resisten o son restringidas, desafían o son desafiadas, ignoran o son ignoradas en su incorporación a la lógica de la globalización. De esta manera la movilidad como característica de la vida urbana no ha sido lo suficientemente considerada en disciplinas como la geografía, la sociología y la antropología urbanas, ni tampoco en otras especialidades asociadas a los estudios urbanos ${ }^{22}$. El análisis del impacto de la movilidad cotidiana cuestiona las concepciones estáticas del espacio urbano, las ideas de fijación y permanencia, ya que las expe-

21 VEGA-CENTENO, 2005.

22 HALL, 2003.

26 revista invi № 68 / Mayo 2010 / Volume № 25: 15-57 the creation of roads, avenues and motorways ${ }^{21}$. Thus, the promotion of movement has played an important role in urban planning. This tendency is increasing as a result of the suburbanization processes in urban centers and the virtual and physical connectivity requirements needed for incorporation into the global circuit.

However, the analysis of urban phenomenon has been generally static, as it tries to understand how individuals live on fixed locations, disregarding or trivializing the movement of people and how they interact with the globalization process. In this way, mobility as a characteristic of urban life has not been properly studied in the fields of urban geography, sociology and anthropology and areas related to urban studies ${ }^{22}$. The analysis of the impact of daily mobility questions the static conception of urban space and the concepts of fixity and permanence, since mobile experiences are fluid, scaled and processual, thus needing a thorough examination ${ }^{23}$.

\footnotetext{
21 VEGA-CENTENO, 2005.

22 HALL, 2003.

23 KAUFMANN, 2002; SHELLER \& URRY, 2003; JARVIS, 2005 ; JARVIS, 2005'; LE BRETON, 2005; SAVAGE, BAGNALL Et Al, 2005.
}

ARTICLE: Exclusion and spatial inequality: An analysis from a daily mobility perspective / Paola Jirón M., Carlos Lange V., María Bertrand S. 
riencias móviles son fluidas, escalares y procesuales, y requieren por ende ser vistas en toda su complejidad $^{23}$.

En este sentido, es importante evitar reducir la movilidad al movimiento y, pese a que el movimiento es un componente importante de la movilidad, no se refiere a lo mismo. Como se estableció anteriormente, la movilidad se refiere a la práctica social de desplazarse a través del espacio-temporal, y no sólo al mero acto de movimiento de algo o alguien, que se refiere al transporte.

A juicio de Urry ${ }^{24}$, los viajes y desplazamientos urbanos no han sido suficientemente investigados salvo por el trabajo de ingenieros, geógrafos y economistas de transporte, que tienden a examinar simples categorías de viaje, como los viajes cotidianos al trabajo. Sin embargo, estas disciplinas explícita o implícitamente derivan hipótesis por medio de la adopción de enfoques deductivos a partir de modelos de comportamiento, suponiendo una toma de decisiones racionales, que luego son puestas a prueba contra datos empíricos para llegar últimamente a una generalización ${ }^{25}$. De esta manera, y suponiendo que los usuarios toman decisiones racionales de transporte, que se traducen

23 KAUFMANN, 2002; SHELLER y URRY, 2003; JARVIS, 2005a; JARVIS, 2005b; LE BRETON 2005; SAVAGE, BAGNALL Et AI. 2005.

24 URRY, 2003b.

25 SCHWAMEN, 2007.
In this sense, it is important not to take mobility from movement, and although movement is an important component of mobility, they do not refer to the same concept. Mobility, as previously stated, refers not only to the act of moving, in reference to transport, but also to the social practice of moving through space-time.

In the opinion of Urry ${ }^{24}$, urban trips and movements have been mainly studied by engineers, geographers and transport economists, who only analyze daily trips to work. Nevertheless, these disciplines, explicitly or implicitly, derive hypothesis through the adoption-assuming a rational decision-making process- of deductive approaches based upon behavior models that are contrasted with empirical data to reach a generalization ${ }^{25}$. In this manner, and assuming rational transport decisions taken by users - which are translated into efficiency and effectiveness of movement and connectivity-transport professionals try to organize daily movement.

\footnotetext{
24 URRY, 2003 ${ }^{\mathrm{b}}$.

25 SCHWAMEN, 2007.
} 
en eficiencia y efectividad en la circulación y conectividad, los profesionales de transporte intentan poner orden o disciplina al movimiento diario.

Para Richmond ${ }^{26}$ esta visión estrecha del transporte no se relaciona tanto con problemas de racionalidad en la disciplina sino con las estrechas preguntas de investigación que plantean los profesionales de transporte. Las decisiones de movilidad debieran también incluir información sobre urbanismo, ciencias sociales, psicología, entre otras $^{27}$. Si bien es cierto que la investigación de comportamiento de viaje ha incorporado análisis más complejos como patrones de roles en las interacciones de hogares, presupuestos de tiempo, planificación de actividades, estilos de vida, y más recientemente tamaño y estructuras de las redes sociales $^{28}$, o uso de suelo ${ }^{29}$, aún requiere mayores aportes provenientes desde el ámbito del urbanismo y las ciencias sociales.

Reconociendo la importancia de dichas conexiones y modelos, el análisis de la movilidad urbana cotidiana requiere abordarse atendiendo a la forma como ellas se organizan en patrones complejos que transforman las relaciones sociales ${ }^{30}$. A medida que la movilidad y la permanencia se revelan

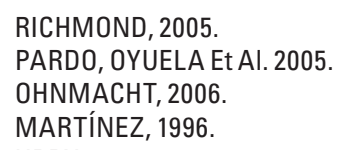

28 revista invi № 68 / Mayo 2010 / Volume № 25: 15-57
Richmond ${ }^{26}$ says that this narrow perspective of transport is more related to narrow questions set out by transport professionals than to rational problems. Mobility decisions should also include information about urbanism, social sciences or psychology, amongst other disciplines ${ }^{27}$. Although research on travel behavior has added more complex analyses; such as patterns of roles in home interactions, time management, activity planning, lifestyles, size and structure of social networks ${ }^{28}$ or land use $e^{29}$, it still needs contributions from urban and social sciences disciplines.

Acknowledging the importance of such connections and models, urban daily mobility analysis should be addressed taking into consideration the way these concepts shape complex patterns, transforming social relationship ${ }^{30}$. As mobility and permanence get more complex, its organization becomes unfeasible, even using the most accurate models.

\footnotetext{
26 RICHMOND, 2005.

27 PARDO, OYUELA Et Al, 2005.

28 OHNMACHT, 2006.

29 MARTINEZ, 1996.

30 URRY, $2003^{\mathrm{a}}$.

ARTICLE: Exclusion and spatial inequality: An analysis from a daily mobility perspective / Paola Jirón M., Carlos Lange V., María Bertrand S.
} 
más complejas y ricas, intentar disciplinar dichos patrones se vuelve inviable hasta por los modelos más sofisticados.

En este sentido, diversas investigaciones ${ }^{31}$ han demostrado que las prácticas de movilidad son híbridas, lo que significa que la mayoría de los viajes tienen más de un objetivo y además cambian con la experiencia. Muchas de las prácticas incluyen periodos de gran variación de descanso o estancamiento, que pueden o no ser explotadas, buscadas o impuestas. De tal modo que resulta necesario entender las situaciones de movilidad y las experiencias de aquellos involucrados, y no sólo la finalidad de la movilidad en diferentes contextos. Este enfoque también requiere comprender los procesos, escalas, diversidad de experiencias de movilidad, a fin de poder entender cómo éstas otorgan significado y afectan las relaciones sociales. La conectividad y eficiencia en la conexión (virtual, física o mental) son importantes, pero las implicancias de dichas conexiones, la experiencia del viaje, las relaciones que éstas tienen con procesos sociales más amplios son más complejos y tienen historias más ricas que contar y por ende requieren mayor investigación.

31 VEGA-CENTENO, 2005; URETA, 2006; SPINNEY, 2007; JIRON $2007 ; 2010$.
In this sense, research ${ }^{31}$ has shown that mobility practices are hybrid, meaning that most of trips have more than one purpose and change depending on experience as well. Many of the practices include periods of variation of rest or stagnation that may or not be exploited, planned or imposed. Therefore, it is important to understand not only the purpose of mobility in different contexts, but also mobility conditions and the experiences of actors involved in it. This approach also needs to understand the mobility processes, scales and diversity of experiences; in order to comprehend how these concepts affect social relationships. While connectivity and efficiency of connection (virtual, physical or mental) are important, implications of such connections, travel experiences and their relationships with broader social processes are more complex and interesting. As a result, these implications need further research.

\footnotetext{
31 VEGA-CENTENO, 2005; URETA, 2006; SPINNEY, 2007; JIRON $2007 ; 2010$.
} 


\section{La exclusión social desde la movilidad}

En La Miseria del Mundo, Bourdieu Et Al. ${ }^{32}$ exploran el sufrimiento social en la sociedad contemporánea marcada por el neoliberalismo, la disolución de la identidad de clase y el repliegue del estado. Examinan cómo las personas con alto nivel de capital económico, cultural y social tienen poder sobre el espacio y tienden a auto-segregarse, mientras aquellos con escaso capital están confinados a lugares que no escogen. En estos últimos lugares, las personas encuentran poco en común, salvo la falta de capital económico, social y cultural. Bajo el lente de la movilidad, esto aparece como una doble exclusión: acceso urbano limitado a los bienes, productos y servicios existentes en una sociedad urbana y fijación espacial con vulnerabilidad aglomerada, creando ciudades segregadas pero también paralelas, donde la gente suele solaparse pero no realmente encontrarse.

Según Scheller y Urry ${ }^{33}$, la mayoría de los teóricos coinciden en ver la exclusión social como un fenómeno espacialmente delimitado y estático. Sin embargo, y en consideración a los antecedentes anteriormente expuestos, es posible plantear que al constituirse en un componente fundamental de

BOURDIEU Et AI, 1999.

SHELLER Y URRY, 2003.

30

revista invi № 68 / Mayo 2010 / Volume № 25: 15-57

\section{Social exclusion from a mobility perspective}

In The Misery of the World ${ }^{32}$, Bourdieu Et Al explore social suffering in this contemporary society governed by neoliberalism, dissolution of class identity and a distant state. It also analyses the freedom that higher income groups have to choose where they want to live, as well as their tendency to self-segregation. Likewise, it examines how lower income groups are forced to live in determined areas. In those places, people have little in common, but their lack of economic, social and cultural capital. Seen from a mobility point of view, this is a double exclusion: limited urban access to goods, products and services in an urban society and a concentrated vulnerability that creates segregated, dual cities where people interact but do not interrelate.

According to Scheller and Urry ${ }^{33}$, most of theorists agree on regarding social exclusion as a spatially delimited and static phenomenon. However, taking into consideration the

\footnotetext{
32 BOURDIEU Et AI, 1999.

33 SHELLER \& URRY, 2003.
}

ARTICLE: Exclusion and spatial inequality: An analysis from a daily mobility perspective / Paola Jirón M., Carlos Lange V., María Bertrand S. 
la vida social urbana contemporánea, la movilidad cotidiana urbana permite incorporar nuevas perspectivas que hacen posible cuestionar y problematizar la forma como se conforman los vínculos y relaciones sociales entre los habitantes de la ciudad, y con ello la noción de exclusión social urbana tal y como tradicionalmente se ha abordado desde las ciencias sociales y los estudios urbanos. En este sentido, el abordaje de la exclusión social desde la perspectiva de la movilidad cotidiana urbana permite problematizar y analizar críticamente el carácter multidimensional, relacional y dinámico de ésta.

El carácter multidimensional de la exclusión social se manifiesta principalmente en el acceso diferenciado y desigual a medios y mecanismos de movilidad urbana cotidiana, y por consiguiente, a los bienes, productos y servicios materiales y simbólicos disponibles dentro de una sociedad urbana.

En este sentido, resulta fundamental comprender la estrecha relación que, existe entre desigualdad y exclusión social en el contexto de un modelo de desarrollo neoliberal. Mientras la desigualdad refiere al proceso de posicionamiento, distribución y apropiación inequitativa de los recursos sociales, políticos, económicos y culturales entre los miembros de una sociedad, incorporando no sólo recursos materiales sino también a recursos inmateriales e intangibles como tiempo, poder, libertad, redes sociales, etc, la exclusión social refiere a las previously mentioned information, it is possible to state that urban daily mobility -given its key role in contemporary urban social life- may incorporate new approaches that question the way social links and relationships among city dwellers are built as well as the concept of urban social exclusion, as it has been traditionally addressed by social sciences and urban studies. In this sense, the study of urban social exclusion, from an urban daily mobility perspective, allows a critical analysis of its multidimensional, relational and dynamic nature.

The multidimensional nature of social exclusion manifests itself in the unequal, differentiated access to means and mechanisms of urban daily mobility. Consequently, the access to material goods, products and services available in an urban society are also uneven.

In this regard, it is essential to understand the close relationship between inequality and social exclusion within the context of neoliberal development. On the one hand, inequality refers to the positioning, distribution and unequal appropriation processes of social, political, economic and cultural resources among society 
limitaciones de acceso y participación a dichos recursos, lo cual coarta las posibilidades que ciertos miembros de la sociedad tienen para insertarse participativamente en las dinámicas y procesos de desarrollo existentes en ésta, generando quiebres en la cohesión social. En pocas palabras, ello significa "hacerse parte" de algo. Esta diferencia conceptual implica que la desigualdad puede o no generar exclusión social.

Un abordaje estático y delimitado de la exclusión social no necesariamente reconoce cómo los automóviles y la tecnología de la información deshace todas las divisiones entre vida pública y privada o cómo se fragmenta la vida cotidiana. Las múltiples formas de movilidad generan grandes desigualdades, especialmente las que surgen del poder de los usuarios 'ricos en dinero - pobres en tiempo', que experimentan un flujo suave a través del espacio limitado y exclusivo, mientras que los 'pobres en dinero - ricos en tiempo' son dejados fuera de estos espacios limitados ${ }^{34}$ o de las movilidades bloqueadas generadas por los barrios cerrados.

Estas divisiones y fragmentaciones constituyen un reflejo del hecho que la accesibilidad está distribuida de manera desigual entre los individuos: no todos tienen igual acceso a sitios de trabajo, ocio y consumo ${ }^{35}$, a actividades y personas, a recursos y oportunidades. Las desigualdades espaciales se

34 WOOD Y GRAHAM, 2004.

35 ALLEMAND, 2003.

32 revista invi № 68 / Mayo 2010 / Volume № 25: 15-57 members. On the other hand, social exclusion refers to participation and access restrictions to resources, reducing the chances of certain groups to take part in social dynamics and development processes, thus breaking social cohesion. In short, that means "being part" of something. This conceptual difference suggests that inequality may or not generate social exclusion.

A narrow, static way of tackling social exclusion does not necessarily identify how automobiles and information technology break the divisions between public and private life, or how daily life gets fragmented. Multiple forms of mobility generate inequality, especially those that have their roots on the power of "rich-no time" users that comfortably move through an exclusive and limited space. On the contrary, "poor-plenty of time" users are excluded from these spaces ${ }^{34}$ and from the blocked mobility created by gated communities.

These divisions and fragmentations are an example of the unequal distribution of

34 WOOD \& GRAHAM, 2004.

ARTICLE: Exclusion and spatial inequality: An analysis from a daily mobility perspective / Paola Jirón M., Carlos Lange V., María Bertrand S. 
relacionan con el acceso al espacio-temporal pero también con la experiencia de la exclusión en movilidad. Esto se debe a que la movilidad afecta varios aspectos de la vida cotidiana, en términos de cómo moverse, cómo establecerse o afincarse, qué se puede tomar y qué está vedado, quién se puede mover libremente y quién lo hace restringidamen$\mathrm{te}^{36}$.

Asimismo, la desigualdad ha sido estudiada y medida principalmente en términos de ingreso económico por medio del análisis de la distribución de la riqueza en la sociedad. En áreas urbanas, ésta ha sido analizada en cuanto a la distribución de ingreso y empleo, entendiéndose como contenedoras de desigualdad. Sin embargo, en los últimos años ha habido un cambio en la comprensión de la desigualdad basada solamente en la localización estructural de clase de los individuos dentro de un orden económico, en la medida que no considera relaciones de poder que no son solamente de clase sino que también pueden atribuirse a identidades de género, etnia, cultura, religión o sexualidad ${ }^{37}$. Dentro del debate europeo, esto ha sido entendido como exclusión social ${ }^{38}$, refiriéndose a las formas en que la marginalidad económica y social tienden a coincidir. En los Estados Unidos, este debate ha sido vinculado al término "subclase", para indicar

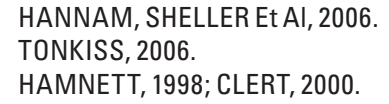

accessibility: not everyone has the same access to the workplace and entertainment places ${ }^{35}$; to activities and other people; to resources and opportunities. Spatial inequality relates to the space-time access and to the mobility exclusion experience. This is due to the effect of mobility on aspects of daily life such as movement, settling down and the freedom that people have to chose and move $e^{36}$.

Likewise, by analyzing the distribution of wealth, inequality has been studied and measured in terms of income. In urban areas, inequality has been analyzed according to the distribution of income and employment. However, during the last years, the understanding of inequality based on structural localization of people belonging to a specific social group has changed, as it does not take into consideration aspects such as sexual identity, ethnic group, culture, religion or gender ${ }^{37}$. In Europe, inequality has been understood as social exclusion ${ }^{38}$, referring to the different ways social and economic marginalization converge. In the United States,

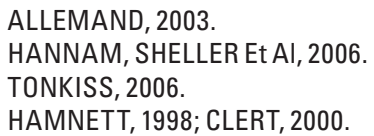


la exclusión radical de los grupos vulnerables de la corriente principal económica y social ${ }^{39}$.

En América Latina la desigualdad y la exclusión social fueron analizadas principalmente desde el punto de vista de los pobres a través del concepto de 'marginalidad'. Pese a ser ampliamente criticado $^{40}$, dicho enfoque tuvo gran reconocimiento como una manera de explicar las grandes desigualdades en las condiciones de vida, exacerbadas por el rápido ritmo del proceso de urbanización. En el contexto actual, esta idea aparece muy cercana a aquellas de 'nueva subclase', 'nueva pobreza', 'nueva marginalidad' o 'marginalidad avanzada', que básicamente describen las condiciones de los crónicamente pobres en los ghettos negros en Estados Unidos o los emigrantes en viviendas sociales en Europa ${ }^{41}$. Esta perspectiva obliga a abordar el carácter relacional de la exclusión social.

En el caso chileno, los enfoques desarrollados sobre desigualdad y exclusión social poseen características similares a las mencionadas anteriormente. Tal como señalan Machinea y Hopenhayn ${ }^{42}$, la desigualdad en la distribución del ingreso constituye una de las variables más consideradas en su abordaje, en la medida que aparece asociada a un

39 WILSON y TAUB 2006; WACQUANT, 2007.

40 LOMNITZ 1975; SCHAEDEL, HARDOY ET AL. 1978; GERMANI 1980; SCHTEINGART 1989; GUTIÉRREZ 1997; GUTIÉRREZ 1999; SCHTEINGART 2001; PERLMAN 2005.

41 PERLMAN 2005.

42 MACHINEA Y HOPENHAYN, 2005.

34 revista invi № 68 / Mayo 2010 / Volume № 25: 15-57 this concept is related to the term "subclass" in order to define the radical exclusion of vulnerable groups belonging to the social and economic mainstream ${ }^{39}$.

In Latin America, by using the concept of "marginality", the poor people were the reference to analyze inequality and social exclusion. Although being criticized ${ }^{40}$, such approach was acknowledged as a tool to understand the inequality of life conditions, intensified by the urbanization process. Today, this idea is close to that of "subclass", "new poverty", "new marginality" or "advanced marginality"; notions that describe the conditions of the chronically poor people who live in the American black ghettos or the immigrants who live in social housing in Europe ${ }^{41}$. From this perspective, the relational nature of social exclusion must be addressed.

In the case of Chile, approaches to inequality and social exclusion have similar features

\footnotetext{
39 WILSON \& TAUB, 2006; WACQUANT, 2007.

40 LOMNITZ, 1975; SCHAEDEL, HARDOY Et AL, 1978; GERMANI, 1980; SCHTEINGART, 1989; GUTIERREZ, 1997; GUTIERREZ, 1999; SCHTEINGART, 2001; PERLMAN, 2005.

41 PERLMAN, 2005.
}

ARTICLE: Exclusion and spatial inequality: An analysis from a daily mobility perspective / Paola Jirón M., Carlos Lange V., María Bertrand S. 
conjunto de brechas entre los grupos de más altos ingresos y aquellos de más bajos ingresos que se remiten a limitaciones en el acceso a bienestar social, formación de capital humano, activos productivos, el ejercicio de derechos ciudadanos, entre otros. Por su parte, Repetto ${ }^{43}$ llama la atención respecto de la interrelación existente entre dicho factor y el acceso a la educación, a puestos de trabajo y al espacio residencial, trilogía que aparece fuertemente asociada con el acceso a oportunidades.

Respecto del último aspecto planteado, el espacio residencial, los procesos de desigualdad y exclusión social han sido analizados casi exclusivamente desde la perspectiva de la segregación residencial. Si bien éste constituye un problema relevante en la conformación de las principales ciudades latinoamericanas y particularmente Santiago de Chile, resulta importante establecer algunas distinciones entre ambos conceptos.

Por una parte, analizar la desigualdad y la exclusión social desde la perspectiva de la segregación residencial remite a una consideración fija y delimitada del problema, donde no se consideran otros ámbitos de actividad desarrollados por las personas (laborales, educacionales, recreacionales) ni tampoco la forma en que diariamente éstos deben desplazarse para desarrollar dichas actividades. Asimismo, los estudios sobre segregación

43 REPETTO, 2005. to those previously mentioned. As stated by Machinea and Hopenhayn ${ }^{42}$, inequality in wealth distribution is one of the most recurrent characteristics to analyze these two concepts, as it relates to the exercise of civil rights, social welfare, human capital training or asset gaps between higher and lower income groups. Repetto $^{43}$ points out the interrelation between inequality and social exclusion and the access to education, employment and residential space. These last three concepts are associated with access to opportunities.

Concerning the last aspect, the residential space and the process of inequality and social exclusion have been mainly analyzed from a residential segregation perspective. Although it is an important problem in the configuration of the main Latin American cities, and particularly Santiago de Chile, there should be distinctions between both notions.

Analyzing inequality and social exclusion from a residential segregation point of view gives a fixed and limited approach to the problem,

42 MACHINEA \& HOPENHAYN, 2005.

43 REPETTO, 2005. 
residencial ponen fuerte énfasis en los factores socioeconómicos que determinan su conformación, sin considerar suficientemente otras variables de carácter social y cultural que también están presentes en los procesos de desigualdad y exclusión social urbana como son los factores étnicos, de género, grupo etario y ciclo de vida, discapacidad, entre otros. Por último, y particularmente respecto de esto último, la consideración de factores culturales como los anteriormente mencionados reflejan la importancia de las consideraciones subjetivas e intersubjetivas asociadas a las experiencias cotidianas de desigualdad y exclusión, y que no aparecen mencionadas ni problematizadas en las variables "objetivas" y mesurables que permiten identificar escalas o modos de la segregación residencial a través de la aplicación de fórmulas matemáticas rellenadas con datos censales o de otras encuestas urbanas.

En definitiva, el carácter multidimencional de la desigualdad y la exclusión social requiere incrementar el nivel de complejidad utilizado hasta ahora en sus perspectivas de análisis.

Por su parte, el carácter relacional de la desigualdad y la exclusión social surge de la inquietud por entender que ella no sólo es relevante o aplicable a los pobres que viven en conjuntos de viviendas sociales, campamentos informales o conventillos aislados del resto de la ciudad y por ende claramente delimitados. Las personas socialmente excluidas where work, education and recreational activities of people and the way people move to develop those activities are not taken into account. In addition, research on residential segregation is focused on the socioeconomic factors that generate it, giving little attention to social and cultural characteristics of inequality and urban social exclusion such as ethnic group, gender, age group, life cycle or disability. These factors show the importance of subjective and intersubjective approaches to daily experiences of inequality and exclusion; they are not mentioned in the "objective" and measurable variables meant to identify scales or forms of residential segregation by using mathematical analysis combined with data from census and surveys.

Then, the multidimensional nature of inequality and social exclusion should be analyzed in more detail.

The relational nature of inequality and social exclusion is rooted in understanding its application beyond the study of people who live in delimited and isolated social housing, shanty towns or tenements. Socially excluded

ARTICLE: Exclusion and spatial inequality: An analysis from a daily mobility perspective / Paola Jirón M., Carlos Lange V., María Bertrand S. 
no siempre se agrupan, sino que pueden estar esparcidas como consecuencia de las circunstancias de vida ${ }^{44}$. Más allá de la cercanía o de la lejanía espacial, lo fundamental del carácter relacional de la exclusión social reside en el hecho que cuando alguien vive una situación de exclusión (adultos mayores, pobres, mujeres, niños, minorías étnicas, discapacitados), alguien está excluyendo ${ }^{45}$. Lyons ${ }^{46}$ menciona que mirar sólo a los excluidos de la sociedad genera el riesgo de tratar los síntomas en vez de la enfermedad. Para este autor, a menos que la exclusión se vea como relacional, donde la situación de algunos es influenciada, causada o relacionada con la de otros u otros procesos, un análisis que se restringa a los pobres (o a las mujeres o a los discapacitados o a las minorías étnicas) difícilmente puede llevar a superar esta situación.

Asimismo, el carácter relacional de la exclusión social también puede observarse a partir de la influencia de la movilidad cotidiana urbana en el surgimiento de nuevas formas de sociabilidad caracterizadas por una co-presencialidad intermitente. Esta consideración ha generado una interesante discusión y debate en las ciencias sociales respecto de las transformaciones que los tradicionales espacios de sociabilidad como el barrio, el trabajo, los clubes sociales y deportivos y principalmente los

\footnotetext{
44 HINE AND GRIECO, 2003

45 BEALL, CRANKSHAW ET AL 2002.
}

46 LYONS, 2003.

ARTíCULO: Exclusión y desigualdad espacial: Retrato desde la movilidad cotidiana / Paola Jirón M., Carlos Lange V., María Bertrand S. people do not always group together, they are also scattered as a consequence of life circumstances $^{44}$. The fundamental relational nature of social exclusion, beyond spatial closeness or proximity, is the fact that exclusion (of elderly people, poor people, women, children, ethnic minorities, and people with disabilities) involves someone who is excluding ${ }^{45}$. Lyons ${ }^{46}$ states that by only examining those socially excluded, exclusion will not be properly addressed. He states that, unless exclusion is regarded as relational, where the situation of some individuals is influenced, caused o related to other processes, an analysis focused on poor people (or women, ethnic minorities or impaired people) is unlikely to solve this problem.

In the same way, the relational nature of social exclusion can be studied from the influence of urban daily mobility on the emergence of new forms of sociability, determined by a sporadic co-presence. There is an interesting debate within social sciences on the transformations

\author{
HINE \& GRIECO, 2003. \\ BEALL, CRANKSHAW Et Al, 2002. \\ LYONS, 2003.
}


espacios de uso público como parques, plazas y calles han experimentado en sociedades con niveles de movilidad cotidiana urbana cada vez más alto. Trabajos como los desarrollados por Augé $e^{47}$ y Delgado $^{48}$ ponen en evidencia la necesidad de matizar y diversificar la existencia de una oposición rígida y abrupta entre "lugares/permanencias" y "flujos/ desplazamientos", que son más bien yuxtapuestas y complementarias. Para estos autores, las prácticas de movilidad cotidiana urbana desarrolladas por los habitantes de las grandes ciudades también genera relaciones sociales significativas entre éstos y el espacio urbano, y si bien no cuentan con el nivel de consenso y estabilidad tradicionalmente requeridas por las ciencias sociales en la medida que promueven formas de identidad, relaciones sociales e integración social más individualizadas y coyunturales, son fundamentales para promover la visibilidad y el reconocimientos de "otros". De esta manera, en ciudades tan segregadas como las chilenas, los espacios de transporte público, lugares de tránsito o estancia corta también pueden constituirse en instancias de sociabilidad, encuentro e interacción social ${ }^{49}$.

El carácter dinámico de la desigualdad y la exclusión social hace referencia a la experiencia del espacio-temporal característica de las sociedades urbanas contemporáneas. En este sentido, una

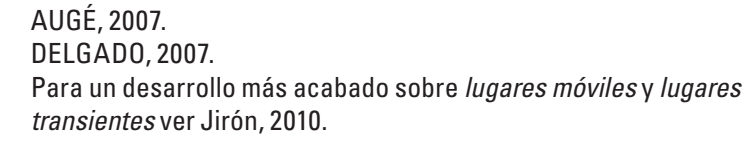

of traditional social spaces -such as the neighborhood, the workplace, social and sports clubs, parks, squares and streets- in societies with high levels of urban daily mobility. Augét7 and Delgado ${ }^{48}$ express the need of specifying and diversifying the differences between places/ spaces and flows/mobility, concepts that are closely related and which complement each other. According to these authors, urban daily mobility generates important social relationships between inhabitants of large cities and urban spaces. Although these links do not meet the standards of social sciences to promote individualized and circumstantial forms of identity, social relationships and social integration, are essential to acknowledge and give visibility to "others". Therefore, in segregated cities, public transport, workplaces and short or long transient places might also be spaces for sociability, encounter and social interaction $^{49}$.

The dynamic nature of inequality and social interaction refers to the space-time experience

\footnotetext{
47 AUGÉ, 2007.

48 DELGADO, 2007.

49 For more detail about mobile places and transient places, see Jirón, 2009.
}

ARTICLE: Exclusion and spatial inequality: An analysis from a daily mobility perspective / Paola Jirón M., Carlos Lange V., María Bertrand S. 
consideración dinámica de estos procesos no sólo conlleva cuestionar su carácter estático a lo largo del tiempo sino también invita a complementar aquellas miradas de carácter sistémico, donde la desigualdad y la exclusión social son analizadas a partir de factores estructurales que las constituyen con otras que pongan en el centro del debate las experiencias a partir de las cuales los sujetos, individuales y colectivos, le asignan sentido y significación. Esta perspectiva implica considerar cómo este tipo de experiencias son encarnadas y situadas por las personas en su cotidianeidad.

Tal como establece Vidal ${ }^{50}$, el desarrollo de una perspectiva como la planteada permite, por una parte, un análisis crítico de su comprensión a través de estereotipos o esquemas predeterminados y estandarizados, tal y como ha sido abordado tradicionalmente desde las ciencias sociales y desde la formulación de políticas públicas. Denominaciones genéricas y de uso común como "los pobres" o "los excluidos" refieren a tipologías o categorías rígidas y predeterminadas, las cuales ocultan la diversidad de condiciones y situaciones, de percepciones y de conciencias, que son constitutivas de las experiencias surgidas desde la cotidianeidad de las personas. La construcción de categorías o esquemas estereotipados, predeterminados y rígidos, dejan al descubierto un conjunto de relatos esca-

50 VIDAL, 2003. of contemporary urban societies. In this regard, a dynamic approach to these processes entails not only the challenging of its static nature through time, but also complementing systemic points of view. From this perspective, inequality and social exclusion are analyzed taking into consideration structural factors combined with other elements, resulting in a discussion of significant experiences for individual and collective subjects. This view implies considering the relationship experiences-people within a daily life context.

As stated by Vidal ${ }^{50}$, a dynamic approach enables a critical analysis of its nature by using predetermined and standardized stereotypes, as it has been traditionally addressed by social sciences and public policies. Generic and common names such as "the poor people" or "the excluded ones" refer to predetermined and unchangeable typologies, hiding the diversity of conditions and situations, perceptions and minds; elements constituent of experiences arising from daily lives of people. Creation of stereotyped, predetermined and unchangeable categories shows a set of stories that are scarcely

50 VIDAL, 2003. 
samente cuestionados respecto de las perspectivas sociales imperantes, y como tal obligan a cuestionar también los discursos construidos desde las ciencias sociales sobre dichos procesos.

Asimismo, y complementando lo expresado en un párrafo precedente, el cuestionamiento de estas construcciones implica también incorporar la revisión y consideración de manera integrada de un conjunto de variables constitutivas de la desigualdad y la exclusión social, como son las ya mencionadas de carácter étnico, de género, grupo etáreo y ciclo de vida, discapacidad, etc. Tradicionalmente las políticas públicas chilenas han intentado aproximarse a sus grupos objetivos desde enfoques parciales, que contemplan el abordaje de estas distintas variables de manera aislada entre sí. En este sentido, la experiencia de la movilidad cotidiana urbana permite considerar este conjunto de variables de manera integrada en su despliegue cotidiano y como tal reconocer las particularidades, diversidades y diferencias existentes entre las distintas personas. Esta centralidad del sujeto en sus experiencias aparece asociada a la primacía de lo cívico y a un mayor protagonismo de los actores sociales en la medida que se les reconoce un papel activo y dinámico en la construcción de la sociedad.

40 revista invi № 68 / Mayo 2010 / Volume № 25: 15-57 challenged by prevailing social perspectives. Consequently, the different statements of social sciences upon such processes should be challenged.

Also, the challenging of these processes implies the integral revision of a series of constituent variables of inequality and social exclusion, such as ethnic origin, gender, age group, life cycle, disability, etc.

Traditionally, Chilean public policies have tried to satisfy the needs of target groups, addressing independently the different variables of exclusion. In this sense, urban daily mobility experience enables considering these variables on a daily context. This allows identifying the characteristics, variety and differences among people. This centrality of the subject on his/her experiences is associated with civic primacy and major participation of social actors, as they are acknowledged as by their active and dynamic role in the formation of society.

ARTICLE: Exclusion and spatial inequality: An analysis from a daily mobility perspective / Paola Jirón M., Carlos Lange V., María Bertrand S. 


\section{Movilidad cotidiana, exclusión social y accesibilidad}

En relación a lo anterior, en Europa a lo largo de los últimos años, los vínculos entre movilidad urbana y exclusión social han sido particularmente analizados por medio del concepto de accesibilidad ${ }^{51}$. Sin embargo, aunque el concepto de accesibilidad ha sido tradicionalmente asociado a mayor o menor provisión de transporte, desde la perspectiva de la movilidad urbana ésto constituye una concepción reductiva. Esto se debe a que la movilidad supone más que viajar desde el punto A al punto B e involucra la experiencia y consecuencias de diversa índole para los viajeros y no viajeros. De esta manera, la movilidad así como su especialidad, pueden a veces ser la causa, y otras la consecuencia de relaciones desiguales, o la manifestación de desigualdades más profundas en la vida urbana.

La literatura sobre movilidad, principalmente de estudios de transporte en Europa y Estados Unidos, entrega varias concepciones de accesibilidad, entendiéndose de una manera sencilla como conectividad desde el punto de vista de la oferta o la

51 CHURCH, FROST ET AL. 2000; HINE AND MITCHELL 2001; SEU 2003; OLVERA, MIGNOT ET AL. 2004; CASS, SHOVEET AL. 2005; LEBRETON 2005; MIGNOT AND ROSALES-MONTERO 2006.
ARTíCULO: Exclusión y desigualdad espacial: Retrato desde la movilidad cotidiana / Paola Jirón M., Carlos Lange V., María Bertrand S.

\section{Daily mobility, social exclusion and accessibility}

In Europe, during the last years, links between urban mobility and social exclusion have been especially analyzed using the concept of accessibility $^{51}$. However, although accessibility is associated to availability of transport services, it is a reductive conception. This is due to mobility is more than traveling from $A$ to $B$, it involves different experiences and consequences of those who travel and those who do not. In this manner, mobility and its derivatives might be the cause or the consequence of unequal relationships; or they might be an example of greater inequality in urban life.

Literature about mobility, mainly American and European research on transport, gives a series of conceptions of accessibility; from the supply and demand point of view, it is simply understood as connectivity ${ }^{52}$.

51 CHURCH, FROST Et Al, 2000; HINE \& MITCHELL, 2001; SEU, 2003; OLVERA, MIGNOT Et Al, 2004; CASS, SHOVE Et Al, 2005; MIGNOT \& ROSALES-MONTERO 2006.

52 MILLER, 1999; BARADARAN \& RAMJERDI, 2001; HINE \& MITCHELL, 2001; KENYON, LYONS Et Al, 2002; HINE \& GRIECO, 2003; KENYON, RAFFERTY Et Al, 2003; MILLER, 2005; KENYON, 2006; KENYON, 2006; MILLER, 2006.

revista invi № 68 / May 2010 / Volume № 25: 15-57 41 
demanda ${ }^{52}$. Sin embargo, para Axhausen Et $\mathrm{Al}^{53}$, estas perspectivas son incompletas en la medida que no abordan la comprensión de los ritmos, rutinas y hábitos que componen la vida cotidiana, cómo la movilidad impacta su acceso a los beneficios urbanos y cómo se relaciona con otros aspectos de la vida urbana. De tal modo que los estudios de comportamiento de viaje podrían ser significativamente realzados si se complementaran con investigación más detallada de tipo cualitativa que explorase las experiencias de movilidad cotidiana.

Desde las ciencias sociales, la accesibilidad constituye un tema clave en la discusión de desigualdad y exclusión ${ }^{54}$. Específicamente en el Reino Unido, la Unidad de Exclusión Social ${ }^{55}$ la ha definido como la forma en que las personas acceden a servicios a costos razonables, en tiempo razonable y con facilidad razonable. Esto refleja que la accesibilidad involucra no sólo aproximarse al transporte sino también a la localización, reparto y distribución de ciertas actividades claves. En este tipo de análisis, un acceso adecuado puede referirse a la exis-

52 MILLER 1999; BARADARAN AND RAMJERDI 2001; HINE AND MITCHELL 2001; KENYON, LYONS ET AL. 2002; HINE AND GRIECO 2003; KENYON, RAFFERTY ET AL. 2003; MILLER 2005; KENYON 2006; KENYON 2006; MILLER 2006.

53 AXHAUSEN ET AL, 2002.

54 CHURCH, FROST ET AL. 2000; BARADARAN AND RAMJERDI 2001; HINE AND GRIECO 2003; KENYON, RAFFERTY ET AL. 2003; LYONS 2003; SCHONFELDER AND AXHAUSEN 2003; CASS, SHOVE ET AL. 2005; MILLER 2006.

55 SEU, 2003.

42 revista invi № 68 / Mayo 2010 / Volume No 25: 15-57
Nevertheless, to Axhausen Et $A l^{53}$, these perspectives are incomplete as they do not provide an understanding of the pace, routines and customs that compose daily life. For that reason, studies on travel behavior might acquire importance if they are complemented with a qualitative, detailed research on daily movement experiences.

In a social sciences context, accessibility is a key subject of discussion in inequality and exclusion ${ }^{54}$. In the United Kingdom, the Social Exclusion Unit ${ }^{55}$ has defined it as the way people have access to services at reasonable costs, time and ease. This means that accessibility involves not only the access to transport, but also localization and distribution of key activities. Following this analysis, proper access may refer to the presence of transport, as well as to the physical and financial access, confidence anthe

53 AXHAUSEN Et Al, 2002.

54 CHURCH, FROST Et Al, 2000; BARADARAN \& RAMJERDI, 2001; HINE \& GRIECO, 2003; KENYON, RAFFERTY Et Al, 2003; LYONS, 2003; SCHONFELDER \& AXHAUSEN, 2003; CASS, SHOVE Et Al, 2005; MILLER, 2006.

55 SEU, 2003. 
tencia de transporte, así como a su conocimiento, confianza en su desempeño o su acceso físico y financiero. En ese sentido, resulta relevante también desarrollar enfoques que aborden la forma en que las personas usan la movilidad para propósitos distintos al transporte, como por ejemplo la forma en que las personas acceden a sus redes de relaciones como sugiere Cass $\mathrm{Et}^{\mathrm{Al}} \mathrm{l}^{56}$. y a lugares como sugiere Jirón ${ }^{57}$.

Para comprender cómo afecta la movilidad a la exclusión social, y adaptando el trabajo de Cass Et $\mathrm{Al}^{58}$, la accesibilidad puede entenderse como la habilidad de negociar el tiempo y espacio para cumplir con las prácticas diarias, mantener relaciones y generar lugares que las personas requieren para su participación social. Pese a que no captura todas las dimensiones de exclusión social, el concepto de accesibilidad aquí adoptado otorga una comprensión más profunda de las implicancias de estar conectado o desconectado, permite mirar a los tipos de conexiones, los tiempos, lugares y relaciones que otorga este acceso y su impacto en la vida cotidiana.

Atendiendo a la consideración de que comprender la relación entre movilidad urbana cotidiana, accesibilidad y exclusión social no solamente pasa por analizar factores como localización de infraestruc-

\footnotetext{
56 CASS Et Al, 2005.

57 JIRÓN, 2007.

58 Op. Cit.
}

ARTíCULO: Exclusión y desigualdad espacial: Retrato desde la movilidad cotidiana / Paola Jirón M., Carlos Lange V., María Bertrand S. understanding of it. This way, it is important to develop approaches aimed at addressing the way people use mobility for purposes other than transport, such as the way people have access to social networks, according to Cass Et $A l^{56}$, and places, as Jirón ${ }^{57}$ suggests.

In order to comprehend how mobility affects social exclusion, and adapting the research of Cass Et $\mathrm{Al}^{58}$, accessibility should be understood as the ability of managing space and time to carry out daily activities, to maintain relationships and to generate places for social participation. This concept of accessibility, although not covering all the dimensions of social exclusion, is useful to broadly understand the implications of being connected or disconnected and to analyze the kind of connections, time, places and relationships of this access, as well as its impact on daily life.

Since understanding the relationship between urban daily mobility, accessibility and social exclusion does not always imply analyzing localization of infrastructure or transport

\footnotetext{
56 CASS Et Al, 2005.

57 JIRON, 2007.

58 Op. Cit.
} 
tura o sistemas de transporte, sino también barreras culturales que previenen a diferentes grupos al mezclarse o encontrarse ${ }^{59}$ a partir de consideraciones de género, edad, ingreso, habilidad, religión, o etnia, se considera relevante abordar tanto las características y capacidades socioculturales de las personas como también las estructuras e infraestructuras existentes que restringen o permiten la movilidad.

Por tal motivo, se sugiere observar el acceso a prácticas, relaciones y lugares según las barreras financieras, físicas, organizacionales, temporales, habilidades y tecnológicas ${ }^{60}$. Las barreras financieras que afectan la movilidad pueden involucrar, por ejemplo, el costo de usar diferentes modos de transporte. Las dimensiones físicas pueden relacionarse a la distancia viajada pero también al aspecto físico y las condiciones de los espacios que se encuentran: caminos, veredas, paraderos, buses, plataformas de metro, senderos de bicicletas, o parques, entre otros. Las restricciones organizacionales se refieren a las múltiples actividades que se realizan de manera regular para coordinar la vida cotidiana e incluyen comprar, ir al médico, pagar cuentas, acceder al trabajo, etc. Las dimensiones temporales se relacionan con la manera en que el día, la noche, las estaciones, las horas de apertura,

59 SHOVE, 2002.

60 Basado en Hagerstrand (1970); Church et al (2000) Cass, Shove et al (2005) y Law (1999).

44 revista invi № 68 / Mayo 2010 / Volume № 25: 15-57 systems, but also cultural barriers -gender, age group, income, ability, religion, ethnic originthat prevent mixing and interrelation among different groups ${ }^{59}$; it is important to address the sociocultural characteristics and capabilities of people and the structures and infrastructures that restrict or enable mobility.

Therefore, the access to practices, relationships and places in relation to economic, physical, organizational, temporal and ability barriers should be studied ${ }^{60}$. Economic barriers affecting mobility might involve the cost of using different means of transport. Physical dimensions might be related to distance and the physical aspect and conditions of roads, pavements, bus stops, buses, subway platforms, cycleways and parks, amongst other places. Organizational restrictions refer to regular multiple activities that coordinate daily life such as buying, going to the doctor, paying bills, commuting to work, etc. Temporal dimensions relate to the way night, day, seasons, opening times and travel length affect mobility decisions. Abilities refer

\footnotetext{
59 SHOVE, 2002.

60 Based on Hagerstrand (1970); Church et al (2000), Cass, Shove et al (2005) and Law (1999).
}

ARTICLE: Exclusion and spatial inequality: An analysis from a daily mobility perspective / Paola Jirón M., Carlos Lange V., María Bertrand S. 
la duración de los viajes, afectan las decisiones de movilidad. Las habilidades se refieren a las capacidades para moverse de maneras específicas, por ejemplo, saber manejar o tener licencia de conducir, saber cambiar llantas, saber arreglar una bicicleta, ser capaz y sentirse cómodo montando una motocicleta, por ejemplo. Las barreras tecnológicas involucran la posibilidad, capacidad de uso y disponibilidad de tecnología para aumentar o facilitar los viajes y sustituir la necesidad de viaje físico, incluyendo Internet o teléfonos móviles, por ejemplo. Cada una de estas barreras se altera cuando se mira a través de las condiciones socio-culturales de los individuos o grupos, incluyendo: género, edad, etapa del ciclo de vida, discapacidad o etnia.

\section{Conclusiones}

Este trabajo ha discutido cómo la movilidad cotidiana urbana constituye en la actualidad uno de los fenómenos más relevantes en la conformación y articulación de la vida urbana contemporánea. Su espacialidad, en particular, opera como clave explicativa fundamental de contenidos tan diversos como las articulaciones parte/todo de contención del crecimiento, los contenidos programáticos to specific capability in terms of movement, such as driving, replacing tires, fixing a bicycle or being able to ride a motorcycle. Technological barriers involve the possibility, use and availability of technology, such as the Internet or mobile phones, to make trips easier and to replace physical trips. Each of these restrictions is altered depending on the sociocultural conditions of people or groups of people, including gender, age group, life cycle, disability or ethnic origin.

\section{Conclusions}

This work has discussed how urban daily mobility is today one of the most important phenomena of urban daily life. Its spatiality is key to understanding aspects such as part/ whole links of growth constraint, programmatic contents of public-private continuum (material, environmental, time), or spatialities of sociabilities derived from mobility. 
(materiales, ambientales, horarios) del continuo público-privado, las espacialidades de las sociabilidades de la movilidad, entre otros.

Así, los procesos de intensificación y expansión urbana (reconversiones, suburbanizaciones ${ }^{61}$ ) configuran las condiciones de experiencia espaciotemporal de la ciudad metropolitana y se insertan en los modos de organización de la movilidad cotidiana masiva.

El espacio -físico- de la movilidad y la espacialización -dinámica- de los desplazamientos masivos se constituyen en recurso intermediador de múltiples bienes ${ }^{62}$. En su consideración clásica, desde un medio técnico, el espacio es visto desde las dinámicas de funcionamiento que reproducen sistemas relacionales imperantes, por ejemplo horarios de funcionamiento de actividades, a través de los cuales los sujetos se integran y participan de los beneficios del tejido de actividades irrigado por esa movilidad. Sin embargo, la experiencia del espacio confirma que la espacialidad en movimiento empieza a ser trabajada como bien per sé.

61 La creación de nuevas centralizaciones y subcentralizaciones simultáneamente concentran y dispersan, especializan y mezclan las localizaciones de actividades según contenidos que desbordan las clasificaciones de la ciudad fordista (de residencia, productivas, recreativas, educacionales).

62 Bienes políticos (opción por modos de desarrollo territorial, bienes de modos de inscripción ambiental, bienes de condiciones de ejercicio de la ciudadanía de la sociabilidad informal), bienes paisajísticos, bienes informativos, bienes de urbanidad, etc.

46 revista invi № 68 / Mayo 2010 / Volume № 25: 15-57
In this way, urban expansion and intensification processes (reconversion and suburbanization ${ }^{61}$ ) configure the conditions of space-time experiences of the metropolitan city, influencing the organization of massive daily mobility.

Physical space of mobility and dynamic spatialization of massive movements are a mediator resource of multiple goods ${ }^{62}$. According to classic, technical conception, space is analyzed from the functioning dynamics that reproduce prevailing relational systems such as the operating schedules of activities. In this context, people integrate and enjoy the benefits derived from mobility. However, space experience confirms that spatial mobility is being analyzed as a good.

In this manner, and being a practice and $a$ specific material culture, spatiality of urban

61 The creation of new centralization and subcentralization concentrates, disperses, spetializes and mixes the localization of activities, according to contents that transcend Fordist city conceptions (about residence, productivity, recreation and education.)

62 Political goods (forms of territorial development, goods of environmental registration, goods of exercise of citizenship of informal sociability), landscape goods, informative goods, urban goods, etc.

ARTICLE: Exclusion and spatial inequality: An analysis from a daily mobility perspective / Paola Jirón M., Carlos Lange V., María Bertrand S. 
En este sentido, y junto con constituirse en una práctica y en una cultura material específica, la temática de la espacialidad de la movilidad cotidiana urbana se revela como plataforma y como recurso de agencias encargadas de intermediar, crear, facilitar y promover las condiciones de inclusión, disponibilidad y acceso a los tejidos de sociabilidades, bienes, productos, servicios de las distintas dimensiones de la vida en sociedad.

Así considerada, la temática de la espacialidad de la movilidad cotidiana urbana masiva abre la posibilidad de desarrollar una problematización de las condiciones espacio-temporales de desigualdad y exclusión social de la vida en sociedad portada, sea por la organización física, sea por las condiciones espacio-temporales de experiencia de la movilidad, en su mutua relación. $\mathrm{O}$, en otros términos: ¿qué condiciones hay en la organización de las condiciones físicas de las ciudades que, independiente de la opción de los interesados, revelan formas de exclusión a partir de las prácticas de la movilidad masiva?; ¿de qué manera inciden esas condiciones en la experiencia espacio temporal de la ciudad?; y ¿qué aparece como materialidad de la ciudad?

Cuando la espacialidad que materializa la organización como sociedad se descifra desde las experiencias de su activación, vía movilidad, des-

ARTíCULO: Exclusión y desigualdad espacial: Retrato desde la movilidad cotidiana / Paola Jirón M., Carlos Lange V., María Bertrand S. daily mobility is a platform and resource of agencies that mediate, create, facilitate and promote conditions of inclusion, availability and access to sociabilities, goods, products and services of the different dimensions of social life.

Spatiality of urban daily mobility enables a critical examination of space-time conditions of inequality and social exclusion in social life. It may be analyzed based on their physical organization or the space-time conditions of mobility experience, in connection with one another. In other words: What conditions are there on physical organization of cities that irrespective of the opinion of those interestedexclude on the basis of massive mobility practices? How do these conditions affect the space-time experience of city? What emerges as materiality of the city?

When the spatiality that materializes organization as society is decoded from the activation of experiences of inequality and exclusion; the substantial (and emotional) spatial relationships turn it from abstraction into tangible knowledge $e^{63}$. This way of thinking

63 Language, operation and representation. 
igualdad y exclusión, ese espacio deja de ser una abstracción y pasa a convertirse en contenidos de saber $^{63}$ desde la materia tangible (intensamente emocional) de las relaciones espaciales. Esta forma de pensar el espacio desde la experiencia da cuenta de una condición epistémica crítica, grounded, situada, encorporada ${ }^{64}$ que recupera las cualidades excluidas en el mundo de las condiciones de la representación disciplinar. Y que refieren al mundo de los espacios abstractos, homogéneos, desencorporados ${ }^{65}$ donde exclusión, desigualdad son referidas a los universos de esa abstracción.

La nueva condición epistémica despliega manejos teóricos, analíticos así como procedimientos y metodologías de validación capaces de trabajar las condiciones dinámicas de complejidad, las articulaciones cuantitativo-cualitativas, multi-escalares y retroactivas características de estos entendimientos de la espacialidad. Las consecuencias sobre los diagnósticos, propuestas, modos de configuración y de organización de los componentes de la espacialidad de la movilidad y de los tejidos por ella irrigados van a ser, sin duda, reveladores de las

63 Lenguajes, operaciones, representaciones.

64 El encorporamiento es un concepto central en filosofía, ciencias, arte que desplaza el centro de atención al cuerpo fenomenal como agente explicativo distinto del cuerpo fisiológico, del cuerpo objeto. El cuerpo fenomenal se forja en sus interacciones a los componentes de configuración espacial como modo de estar-en-el mundo singulares de los que emergen las diferentes culturas del habitar.

Ver cita anterior. space from experience reflects a critical, grounded, present and embodied ${ }^{64}$ epistemic condition that recovers those characteristics excluded in the world of the conditions of disciplinary representation, referring to the abstract, homogeneous and unembodied ${ }^{65}$ spaces where exclusion and inequality are the universes of such abstraction.

The new epistemic condition provides theoretical and analytical frameworks and methodologies and procedures to address complex dynamical conditions and quantityquality articulation, multiscale and retroactive characteristics of spatiality. The consequences of diagnoses, proposals, forms of configuration and organization of spatiality of mobility components and conditions derived from it will add new visions, regarding previous ways of thinking about space, and will constitute a reference for future analysis. This approach

64 Embodiment is a central concept in philosohy, science and art that displaces the center of attention to the phenomenal body as an explanatory agent, distinct from the physiological body, the object body. The phenomenal body isshaped in its interactions to the components of the spatial configuration as a singular way of being-in-the-world from which different cultures of inhabiting emerge.

65 Op. cit.

ARTICLE: Exclusion and spatial inequality: An analysis from a daily mobility perspective / Paola Jirón M., Carlos Lange V., María Bertrand S. 
anteriores maneras de pensar el espacio y significativos de lo que importa empezar a considerar. Lo anterior adquiere relevancia en la medida que permite poner sobre el tapete los alcances teóricoconceptuales desarrollados recientemente sobre ambos conceptos; también permiten analizar los vínculos y relaciones existentes entre ambos y su importancia para la comprensión del espacio urbano, y por último, permite poner en el centro de la discusión a los sujetos urbanos como principales protagonistas de los conceptos en discusión.

Respecto del primer planteamiento teórico-conceptual, importa determinar los contenidos de saber de la dimensión espacial de la movilidad urbana cotidiana ${ }^{66}$. Enfocado desde la objetividad de las situaciones y condiciones creadas por la manera de inscribir relaciones, vínculos, sociabilidades en la materialidad de las cosas, en la intersomaticidad ${ }^{67}$ y en las estructuras del mundo físico, el tema convoca paletas de procedimientos mixtos, heurísticos, de operaciones de mapeo activadas y calibradas por esas performances.

66 Que se articula a condiciones de experiencia espacial de las distintas modalidades de exclusión del cuerpo social.

67 Concepto elaborado por el filósofo Formaggio para caracterizar las condiciones de una experiencia corporal estética del mundo físico elaborada, compartida con las otras personas inmersas en idéntico encuentro. Siguiendo a Choay (2006), el concepto de intersomaticidad se refiere al aspecto fundacional de la condición de "urbanidad". is important as it sets out the theoreticalconceptual contributions developed recently on both concepts; analyses the links and relationships between both concepts and their importance to the understanding of urban space; and it sets urban subjects as key figures in the concepts in discussion.

In regard to the first theoretical-conceptual approach, it is important to determine the knowledge contents of the spatial dimension of urban daily mobility ${ }^{66}$. Considering the objectivity of situations and conditions created from the way relationships, links and sociabilities are set on materiality of things, intersomaticity ${ }^{67}$ and structures of the physical world, the approach presents different mixed, heuristic and mapping procedures activated and determined by these performances.

66 Related to the spatial experience conditions of the different forms of social exclusion.

67 The concept has been elaborated by italian philosopher Formaggio to characterize the conditions of astatic corporeal experience of the physical world elaborated with other persons immersed in identical encounters. Following Choay (2006), the concept of intersomaticity refers to the foundational aspects of the condition of "urbanity".

revista invi № 68 / May 2010 / Volume No 25: 15-57 49 
Respecto del segundo planteamiento, y en consonancia con lo anteriormente referido ${ }^{68}$, permite replantear, explorar y cuestionar los contenidos, consecuencias inmediatas y mediatas de conceptos reveladores de modos de inserción en la ciudad. El replanteamiento epistémico inicial obliga a repensar el carácter estructural y relacional de la espacialización de los fenómenos sociales de la exclusión, lo que reconoce los marcos fijos y condiciones de dinamismo. La espacialidad situada como proceso estructurado en la extensión, trabajado por reconfiguraciones permanentes de sus componentes y modos de activación, abre a las posibilidades de manejo, reconducción y re-escritura que visibiliza puntos críticos.

Por último, y respecto del tercer planteamiento, una perspectiva como la propuesta promueve el reconocimiento a los fenómenos de "producción del espacio" que revelan su profundidad, su espesor vivencial y simbólico, condición indispensable para su manifestación en tanto dominio público, bien durable, resistente a privatismos de todo tipo. Opción que habla de la capacidad de escucha, dialógica, reconocimiento de la pluralidad, heterogeneidad, diferencias, diversidades sociales, cul-

68 Entender la espacialidad de la movilidad urbana cotidiana tanto como ejercicio de prácticas necesarias, recurrentes desplegándose en estructuras y sistemas que lo configuran como recurso, como bien público que permite acceder a bienes, a productos, a intercambios, sociabilidades entre todo lo así conectado: personas, silencios, animaciones, paisajes ...
Concerning the second approach, and consistent with the previous paragraph ${ }^{68}$, it enables the reconsidering, exploration and questioning of the contents, immediate and intermediate consequences of concepts that reveal forms of integration in the city. The epistemic redefinition calls for rethinking the structural and relational nature of spatialization of the social phenomena of exclusion, acknowledging the frameworks and conditions of dynamism. Spatiality situated as a process structured on extension, and developed by constant reconfigurations of its components and forms of activation, enables managing, redirectional and reorganizational possibilities, identifying critical aspects.

In relation to the third approach, the proposed perspective promotes the phenomena of "space production", revealing its depth and experiencebased and symbolic density, essential condition for its manifestation on public domain, a durable good that resists all kinds of privation. This option is about comprehension, dialogue,

68 Understanding the spatiality of urban daily mobility as both an exercise of critical, recurrent practices in structures and systems; and as a public good that enables access to goods, products, exchanges, sociabilities among all connected: people, stills, animation, landscapes...

ARTICLE: Exclusion and spatial inequality: An analysis from a daily mobility perspective / Paola Jirón M., Carlos Lange V., María Bertrand S. 
turales pero, sobre todo, de experiencia emocional del espacio que transforman al "sujeto" anónimo en ciudadano, en nodos de membresías dinámicas suscitadas por el mundo literalmente a su alcance. Visibilizando los caminos para los nuevos tejidos espacio-temporales de las sociedades del presente: solidarias e inclusivas a la par que respetuosas de diferencias e individualidades, durables a la par que flexibles, reconocibles a la par que innovadores. Visibilizando, en otros términos, los caminos de acceso al rostro por venir de los espacios de vida.

La relectura crítica de los enfoques de la espacialidad a partir de la movilidad cotidiana masiva en su articulación con la experiencia de desigualdad y exclusión social, busca plantear la gravedad del momento epistémico inicial y, sacando las conclusiones de lo que así se revela, trazar el retrato de su realidad en el espacio metropolitano de Santiago de Chile. Reconociendo el desafío teórico, metodológico y práctico que esto implica, el proyecto de investigación sobre el cual se basa este trabajo pretende penetrarse precisamente en este ámbito de indagación. A partir del cual se busca dilucidar la espacialidad de la movilidad cotidiana como causa, consecuencia y manifestación de las diversas formas de exclusión social aquí discutidas. Esta espacialidad también dará cuenta del continuo que existe en las experiencias de inclusión/exclusión, y de las posibilidades de sociabilización que allí se develan. Finalmente, al develar estas formas de acknowledging of plurality, heterogeneity, differences, social diversity and most important, emotional experience of space aspects that turn the anonymous "individual" into a citizen, in groups of dynamic memberships generated by their access to the world. It identifies the new space-time structures for contemporary societies: caring and inclusive communities that are also respectful with differences and individualities; durable and flexible; recognizable and innovative. It identifies the access for new life spaces.

The critical re-examination of approaches to spatiality, from the perspective of urban daily mobility and its connection with inequality and social exclusion experiences, seeks to set out the seriousness of the initial epistemic moment; and, by drawing conclusions, define its reality in the metropolitan space of Santiago de Chile. By acknowledging the theoretical, methodological and practical challenges of such exercise, this research focuses on that area of investigation. It is intended to clarify spatiality of daily mobility as the cause, effect and manifestation of the different forms of social exclusion discussed throughout this article. This spatiality will also analyze the continuum between inclusion and exclusion experiences, as well as the 
espacio y espacialidad, nuevos diagnósticos replantean las formas en que se interviene la ciudad, los cuales se encuentran en profundo cuestionamiento a partir de este nuevo enfoque que aquí se presenta.

\section{Bibliografía / Bibliography}

ALLEMAND, S. The sense of movement. En: International Colloquium "The sense of movement. Modernity and mobilities in cotemporary urban societies", organised by IVM, Centre culturel international de Cerisy-la-Salle, Paris, France, Institute pour la ville en mouvement.

AUGE, M. Por una antropología de la movilidad. Barcelona. España, Ed. Gedisa, 2007. 96 pp. ISBN: 8497842358.

AXHAUSEN, K; ZIMMERMAN, A. ET AL. "Observing the rhythms of daily life: A six-week travel diary", Transportation 29: 95-124. 2002. ISSN 00494488

BARADARAN, S. AND F. RAMJERDI (2001). "Performance of Accessibility Measures in Europe". Journal of Transportation and Statistics. 4 (2-3): $31-48$, September/December 2001. ISSN: 10948848 .

52 revista invi № 68 / Mayo 2010 / Volume № 25: 15-57 possibilities of sociabilization derived from it. Finally, by revealing the forms of space and spatiality, new diagnoses reconsider the forms of city intervention, which are questioned in line with the approach developed in this article.

BEALLL, J., 0. CRANKSHAW, et al. Uniting a Divided City. Governance and Social Exclusion in Johannesburg. London,UK: Earthscan Publications Ltd, 2002. 237 pp. ISBN 1853839213.

BOURDIEU, P. The weight of the world: social suffering in contemporary society. Cambridge, UK, Polity Press, 1999. 646 pp. ISBN 9780745615936.

BOURDIN, A. Workshop 4: Hypermodern individuals? En: (2003, Paris, France) International Colloquium The sense of movement. Modernity and mobilities in cotemporary urban societies. Paris, France. IVM, Centre culturel international de Cerisy-la-Salle, Institute pour la ville en mouvement.

CASS, N; SHOVE, E; Et Al. "Social Exclusion, mobility and access". En: The Sociological Review. 53 (3): pp. 539-555, August 2005. ISSN 0038-0261.

ARTICLE: Exclusion and spatial inequality: An analysis from a daily mobility perspective / Paola Jirón M., Carlos Lange V., María Bertrand S 
CHOAY, F. Pour una anthropologie de l'espace. Paris, Seuil. 2006.

CHURCH, A; FROST, M; Et Al. "Transport and social exclusion in London". En: Transport Policy 7 (3): 195-2005. July 2000. 0967-070X.

CLERT, C. "Policy Implications of a Social Exclusion Perspective in Chile: Priorities, Discourse and Methods in Question", Ph.D. Thesis, London School of Economics, 2000.

CRESSWELL, T. On the Move. Mobility in the Modern Western World. New York, USA: Routledge, 2006. 327 pp, ISBN 0415952557 (hbk.).

DELAUNAY, D. "Relaciones entre pobreza, migración y movilidad: dimensiones territorial y contextual". Revista Notas de Población (84): 87-130, Octubre 2007, ISSN 1681-0333.

DELGADO, M. Sociedades Movedizas. Pasos hacia una antropología de las calles. Barcelona, España: Anagrama, 2007. 278 pp. ISBN: 9788433962515.

DE MATTOS, CARLOS A. Santiago de Chile, globalización y expansión metropolitana: lo que existía sigue existiendo. EURE [en línea]. 1999, vol. XXV, no. 76 [citado 2009-11-09], pp. 29-56. Disponible en Internet: http://www.eure.cl//articulos/393/ santiago-de-chile-globalizacion-y-expansionmetropolitana-lo-que-existia-sigue-existiendo/. ISSN 0717-6236.

DUCCI, MARÍA ELENA. Santiago: territorios, anhelos y temores. Efectos sociales y espaciales de la expansión urbana. EURE [en línea]. 2000, vol. XXVI, no. 79 [citado 2009-11-09], pp. 5-24. Disponible

ARTíCULO: Exclusión y desigualdad espacial: Retrato desde la movilidad cotidiana / Paola Jirón M., Carlos Lange V., María Bertrand S. en Internet: http://www.eure.cl//articulos/408/ santiago-territorios-anhelos-y-temores-efectossociales-y-espaciales-de-la-expansion-urbana/. ISNN 0717-6236.

GALETOVIC, A; JORDAN, R. "Santiago: ¿dónde estamos? ¿hacia dónde vamos?". En: GALETOVIC, A. (ed). Santiago: dónde estamos y hacia dónde vamos. Santiago de Chile, Centro de Estudios Públicos, 2006. pp. 25-72. ISBN 956-7015-39-2.

GERMANI, G. Marginality. New Brunswick, USA, Transaction books. 1980. 98 pp. ISBN 0878552359.

GUTIÉRREZ, A. La pobreza desde adentro o las estrategias de reproducción social. [en línea] Primer Congreso Internacional "Pobres y Pobreza en la Sociedad Argentina". Quilmes, Argentina, Universidad Nacional de Quilmes. 1997, <http:// www.naya.org.ar/congresos/indices/indice-pob2. htm> [fecha de consulta: junio 20, 2007].

GUTIÉRREZ, A. Reflexiones teórico-metodológicas en torno al análisis de la pobreza. En: Congreso de la Asociación Latinoamericana de Sociología (22, 1999, Concepción, Chile), Asociación Latinoamericana de Sociología.

HÄGERSTRAND, T. "What about people in regional science?" Papers in Regional Science 24(1): 7-21, January 1970. ISSN: 1056-8190.

HALL, T. Car-ceral Cities: Social Geographies of Everyday Urban Mobility. En: MILLES, M and HALL T: Urban Futures. Critical commentaries on shaping the city. Londres, UK, Routledge. 2003, pp 92-106. ISBN 0415266939.

revista invi № 68 / May 2010 / Volume № 25: 15-57 
HAMNETT, C. Social Polarisation, Economic Restructuring and Welfare State Regimes. En: MUSTERD, S. and OSTENDORF, W. Urban Segregation and the Welfare State. Inequality and exclusion in western cities. London, UK, Routledge, 1998, pp. 1-27. ISBN 0415170591.

HANNAM, K.; SHELLER, M. Et Al. "Editorial: Mobiilties, Immobilities and Moorings". Mobilities 1(1): 1-22, March 2006. ISSN: 1745-0101.

HINE, J. AND GRIECO, M. "Scatters and clusters in time and space: implications for delivering integrated and inclusive transport". Transport Policy 10: 299-306. Jan 2003. ISSN: 0967-070X.

HINE, J. AND MITCHELL, F. "Better for Everyone? Travel Experiences and Transport Exclusion". Urban Studies 38(2): 319-332, February 2001. ISSN: 0042-0980.

JARVIS, H. "Moving to London time. Household co-ordination and the infrastructure of everyday life". Time \& Society 14(1): 133-154. March 2005a. ISSN: 1461-7463.

JARVIS, H. Work/Life City Limits. Comparative Households Perspectives. London, Palgrave Macmillan, 2005b, pp. 277. ISBN 1403914966 (cloth).

JARVIS, H., PRATT, A. C., et Al. The Secret Life of Cities. The Social Reproduction of Everyday Life. New York, Pearson Education. 2001, 199 PP. ISBN 0130873187.

54 revista invi № 68 / Mayo 2010 / Volume No 25: 15-57
JIRÓN, P. "Unravelling Invisible Inequalities in the City through Urban Daily Mobility. The case of Santiago de Chile". Swiss Journal of Sociology 33(1 Special Issue on Space, Mobility and Inequality): 45-68, 2007. ISSN: 0379-3364.

JIRÓN, P. Repetition and Difference: Rhythms and Mobile Place-making in Santiago de Chile. En: EDENSOR, T (ed). Geographies of Rhythm: Nature, Place, Mobilities and Bodies, Ashgate Publishing Ltd, Aldershot, 2010, pp.129-143

KAUFMANN, V. Re-thinking Mobility. Contemporary sociology. Aldershot, UK, Ashgate, 2002. 112 pp. ISBN 0754618420.

KENYON, S. "The 'accessibility diary': Discussing a new methodological approach to understand the impact of Internet use upon personal travel and activity participation". Journal of Transport Geography 14 (2), p.123-134, Mar 2006a. ISSN: 0963-6923.

KENYON, S. Reshaping patterns of mobility and exclusion? The impact of virtual mobility upon accessibility, mobility and social exclusion. En: Sheller, M. and Urry, J., eds. Mobile technologies of the city. Networked Cities. Routledge, London, 2006b, pp. 102-120. ISBN: 9780415374347.

KENYON, S; LYONS, G. Et Al. Transport and social exclusion: investigating the possibility of promoting inclusion through virtual mobility. En: Journal of Transport Geography, 10 (3), p.207-219, Sep 2002. ISSN: 0963-6923.

ARTICLE: Exclusion and spatial inequality: An analysis from a daily mobility perspective / Paola Jirón M., Carlos Lange V., María Bertrand S. 
KENYON, S; RAFFERTY, J; Et Al. "Social Exclusion and Transport in the UK: A Role for Virtual Accessibility in the Alleviation of Mobility-Related Social Exclusion". Journal of Social Policy 32(3): 317338. Jan 2003. ISSN: 0047-2794.

LAW, R. "Beyond 'women and transport': towards new geographies of gender and daily mobility". Progress in Human Geography 23(4): 567-588, December 1999. ISSN: 0309-1325.

LE BRETON É. Bouger pour s'en sortir. En: Mobilité quotidienne et intégration sociale, Paris, Armand Colin, 256 p., 2005.

LOMNITZ, L. Cómo sobreviven los marginados. México DF, México, Ed Siglo XXI. 1975. 229 pp, ISBN 9682302005 .

LYONS, G. "The introduction of social exclusion into the field of travel behaviour". Transport Policy 10: 339-342. Oct 2003. ISSN: 0967-070X.

MACHINEA, J; HOPENHAYN, M. La Esquiva Equidad en el Desarrollo Latinoamericano. Santiago de Chile, CEPAL, 2005, 53 pp. Serie Informes y Estudios Especiales.

MARTÍNEZ F. MUSSA: A Land Use Model for Santiago City. Transportation Research Record 1552: Transportation Planning and Land Use at State, Regional and Local Levels. 1996, pp. 126 -134.

MAY, J. AND THRIFT, N. Introduction. En: MAY, J. and THRIFT, N. Timespace. Geographies of temporality. London, UK, Routledge, 2001. p 1-46. ISBN 0415180848(pbk).

ARTíCULO: Exclusión y desigualdad espacial: Retrato desde la movilidad cotidiana / Paola Jirón M., Carlos Lange V., María Bertrand S.
MIGNOT, D. AND ROSALES-MONTERO, S. Vers un droit a la mobilite pour tous. Inegalites, territoires et vie quotidienne. Paris, France, PUCA Plan Urbanism Construction Architecture. 2006. 112 pp. ISBN: 9782110061997.

MILLER, H. Measuring Space-time Accessibility Benefits within Transportation Networks: Basic Theory and Computational Procedures. En: Geographical Analysis 31: 187-212. January 1999. ISSN: 0016-7363

MILLER, H. Place-based Versus People-based Accessibility. En: LEVINSON, D AND KRIZEK, K. J. Access to Destinations. London, UK, Elsevier. 2005. pp. 63-89.

MILLER, H. Social Exclusion in Space and Time. En: AXHAUSEN K. W. Moving through nets: The Physical and Social Dimensions of Travel. Selected papers from the 10th International Conference of Travel Behaviour Research H. Elsevier Science Publishing Company, 2006, pp. 353-380. ISBN: 9780080442136.

OHNMACHT, T. Mapping Social Networks in Time and Space. Arbeutsberichte Verkehr und Raumplanung. Zurich, IVT, ETH Zurich: 33. 2006.

OLVERA, L.; MIGNOT, D; PAULO, C. Daily Mobility and Inequality: The Situation of the Poor. En: Built Environment 30(2): 153-160. June 2004. ISSN: 0263-7960.

PARDO, C.; OYUELA, R. Et Al. "Time, speed and space perception in three modes of transport". Universitas Psychologica 4(3): 339-348. Octubre-diciembre 2005. ISSN 1657-9267.

revista invi № 68 / May 2010 / Volume № 25: 15-57 55 
PERLMAN, J. E. The myth of marginality revisited: The case of favelas in Rio de Janeiro, 1969-2003. En: Urban Research Symposium 2005 "Land Development, Urban Policy and Poverty Reduction" ( $3^{\circ}$, 2005, Brasilia, DF, Brazil World Bank, Institute of Applied Economic Research IPEA). Disponible en web: <http://www.worldbank.org/urban/symposium2005/index.html>

REPETTO, A. "Desigualdad de Ingresos y Oportunidades en Chile". En: MELLER, P. (Ed). La Paradoja Aparente. Equidad y Eficiencia: Resolviendo el Dilema. Santiago de Chile, Ed. Taurus, 2005. pp. 409-436. ISBN 9562394085.

RICHMOND, J. Transport of Delight. The Mythical Conception of Rail Transit in Los Angeles. Akron, USA, The University of Akron Press. 2005. 498 p. ISBN: 1884836941.

SAVAGE, M; BAGNALL, G; Et Al. Globalisation and Belonging London, UK., SAGE. 2005. 233 p. Serie: Theory, culture \& society. ISBN: 0761949852.

SCHAEDEL, R; HARDOY, J. Et Al. Urbanization in the Americas from its Beginnings to the Present. The Hague, Nehterlands, Mouton Publishers. 1978. 676 pp. Serie: World anthropology. ISBN: 0202900541.

SCHONFELDER, S. AND AXHAUSEN K.W. "Activity spaces: measures of social exclusion?". Transport Policy 10 (3): 279-286. Oct 2003. ISSN: 0967-070X.

SCHTEINGART, M. Las ciudades latinoamericanas en la crisis. Problemas y desafíos. México DF. Mexico, Editorial Trillas. 1989. 286 pp. ISBN: 9682429242.

56 revista invi № 68 / Mayo 2010 / Volume № 25: 15-57
SCHTEINGART, M. "La División Social del Espacio en las Ciudades". Perfiles Latinoamericanos (19). pp. 13-31, 2001. ISSN: 0188-7653.

SCHWAMEN, T. Analytical and cultural understanding of everyday mobility and beyond. American Association of Geographers Annual Meeting. San Francisco, AAG. 2007.

SECTRA. Informe Ejecutivo Encuesta origen-destino de viajes 2001-2002. [en línea] Secretaría de Transporte, Ministerio de planificación, Gobierno de Chile, Santiago. [consulta: 2009-11-09]. Disponible en: http://www.sectra.cl/contenido/bases_datos_sig/ encuestas_movilidad/encuestas> SEU. Making the Connections: Final Report on Transport and Social Exclusion. London, UK, Social Exclusion Unit. Office of the Deputy Prime Minister. 2003. 147pp.

SHELLER, M AND URRY, J. "Mobile transformations of 'public' and 'private' life". Theory, Culture and Society 20(3): 107-125+157. Jun 2003. ISSN: 02632764.

SHELLER, M AND URRY, J. "The new mobilities paradigm”. Environment and Planning A 38 (2): 207226. Jun 2006. ISSN: 1472-3409.

SHOVE, E. Rushing around: coordination, mobility and inequality. Paper presented to ESRC Mobile Network Meeting, Department for Transport, London, October; copy available from Department of Sociology, Lancaster University, Lancaster. Disponible en Web: <http://www.comp.lancs.ac.uk/sociology/ papers/Shove-Rushing-Around.pdf>. 2002.

ARTICLE: Exclusion and spatial inequality: An analysis from a daily mobility perspective / Paola Jirón M., Carlos Lange V., María Bertrand S. 
SPINNEY, J. Cycling the city: movement, meaning and practice. Department of Geography. London, Royal Holloway, University of London. PhD Thesis: 419. 2007.

SZERSZYNSKI, B. AND URRY, J. "Visuality, mobility and the cosmopolitan: inhabiting the world from afar". The British Journal of Sociology 57(1): 113131. Mar 2006. ISSN: 0142-5692.

TONKISS, F. Contemporary Economic Sociology. Globalisation, production, inequality. London, UK., Routledge. 2006. 196 pp. ISBN: 9780415300940.

URETA, S. Machines for living in: communication technologies and everyday life in times of urban transformation. Media and Communications. London, London School of Economics and Political Science. PhD Thesis: 241. 2006.

URRY, J. "Social networks, travel and talk". En: British Journal of Sociology. 54(2): 155-175. Jun 2003. ISSN: 0142-5692. 2003a.

URRY, J. Workshop 1: Beyond societies. En: International Colloquium "The sense of movement. Modernity and mobilities in cotemporary urban societies" organised by IVM, Centre culturel international de Cerisy-la-Salle, Paris, France, Institute pour la ville en mouvement. 2003b.

URRY, J. Connections. En: Environment and Planning D: Society and Space, 22 (1). 2004. pp. 27-37. ISSN 0263-7758.
URRY, J. Mobilities. Cambridge, UK., Polity Press. 335 pp. 2007. ISBN: 9780745634180 (hbk.).

VegA-CentenO, P. La Movilidad Espacial en los Procesos Urbanos. Dinámicas de la vida cotidiana popular en Chosica. Unidad de Arquitectura. Lovaina-la-Nueva, Universidad Católica de Lovaina. Tesis de Doctorado en Arquitectura: 439. 2005.

VIDAL, F. La Perspectiva Fenomenológica de la Exclusión Social. [En línea]. INJUVE, 2003 [consulta: 2009-11-09]. Disponible en: http://www.injuve. migualdad.es/injuve/contenidos.downloadatt. action?id=656074931.

WACQUANT, L. Urban Outcasts: A Comparative Sociology of Advanced Marginality. Cambridge, Malden, Polity Press. 2007. 342 pp. ISBN: 9780745631257 (pbk.)

WILSON, WJ AND TAUB, R. There Goes The Neigorhood: Racial, Ethnic, and Class Tensions in Four Chicago Neigorhoods and Their Meaning for America. New York, Knopf, 2006. 228 pp. ISBN: 0394579364 (alk. paper).

W00D, D. AND S. GRAHAM. Permeable Boundaries in the Software-sorted Society: Surveillance and the Differentiation of Mobility. Alternative Mobility Futures, Lancaster, UK, Lancaster University. 2004. 